\title{
Boron coordination and B/Si ordering controls over equilibrium boron isotope fractionation among minerals, melts, and fluids
}

Yin-Chuan Li a, Hai-Zhen Wei a, *, Martin R. Palmer b, Shao-Yong Jiang c, Xi Liu a, Anthony E. Williams-Jones d, Jing Ma e, Jian-Jun Lu a, Yi-Bo Lin a, Ge Dong a a State Key Laboratory for Mineral Deposits Research, School of Earth Sciences and Engineering, Nanjing University, Nanjing 210023, PR China

b School of Ocean and Earth Science, NOC, University of Southampton, European Way, Southampton SO14 3ZH, UK

c State Key Laboratory of Geological Processes and Mineral Resources, School of Earth Resources, China University of Geosciences, Wuhan 430074, PR China

d Department of Earth and Planetary Sciences, McGill University, Montreal H3A OE8, Canada e Key Laboratory of Mesoscopic Chemistry of MOE, School of Chemistry \& Chemical Engineering, Nanjing University, Nanjing 210023, PR China 


\section{A B S T R A C T}

The high mobility of boron during fluid-rock interaction makes it an effective tracer for the sources of magmatic and metamorphic fluids, as recorded in minerals such as tourmaline and muscovite. Although advances have been made in quantifying the fractionation of boron isotopes among different phases, boron isotope fractionation in complex silicate melts remains poorly understood. Here, we propose appropriate models for the $\mathrm{BO}_{3}$ and $\mathrm{BO}_{4}$ units in silicate melts covering a wide range of chemical compositions and boron coordination structures in silicate magmas, and report the results of a theoretical investigation of boron isotope fractionation among silicate melt, minerals and fluids using a first principles theoretical approach. A comparison of measured and calculated $\alpha$ factors in mineral-melt and fluid-melt systems shows good agreement, suggesting the applicability of a simplified treatment of boron coordination structures in silicate melt. The results of this study show that the proportion of trigonal/tetrahedral coordinated boron and the $\mathrm{B} / \mathrm{Si}$ ordering in silicate tetrahedral layers control the boron isotope fractionation among different phases, and that the effect of chemical composition is minor (less than $2 \%$ at $600 \mathrm{~K}$ ). The temperature-dependent boron isotope fractionations are described as $1000 \ln \alpha_{\text {mica-basic fluid }}=0.8-2.4 \times(1000 / \mathrm{T})-0.8 \times(1000 / \mathrm{T})^{2}$, $1000 \ln \alpha_{\text {mica-acidic fluid }}=7.0-14.0 \times(1000 / \mathrm{T})-1.2 \times(1000 / \mathrm{T})^{2}$ and $1000 \ln \alpha_{\text {mica-tur }}=1.9-5.4 \times$ $(1000 / \mathrm{T})-3.4 \times(1000 / \mathrm{T})^{2}\left(\mathrm{~T}\right.$ is temperature in Kelvins). At magmatic temperatures, $\Delta^{11} \mathrm{~B}$ values between mineral/fluid and melt also vary with the proportion of the $\mathrm{BO}_{4}$ unit in the melt. This study underpins the applicability of the white mica-tourmaline geothermometers and boron isotopes for fluid source identification, and also offers an explanation of boron isotope fractionation in systems that contain complex silicate melts.

\section{Introduction}


Boron has two stable isotopes, ${ }^{10} \mathrm{~B}$ and ${ }^{11} \mathrm{~B}$, and their abundance ratio (expressed as $\delta^{11} \mathrm{~B}$ ) varies by over $100 \%$ in nature. Consequently, boron isotopes have been widely used to interpret geochemical cycles and interactions among magmas, minerals and aqueous fluids (e.g., Williams et al., 2001). The high mobility of boron in aqueous fluids enables boron isotopes to provide important insights into a variety of igneous and metamorphic processes in which such fluids participate. Because of the high sensitivity of $\delta^{11} \mathrm{~B}$ to changes in the fluid source, pressure temperature $(\mathrm{P}-\mathrm{T})$ conditions of crystallization, and phase transitions such as boiling, great attention has been paid to tourmaline group minerals to track the sources of magmatic and hydrothermal fluids (e.g., Palmer and Slack, 1989; Palmer and Swihart, 1996; Jiang et al., 2000; Zheng et al., 2016), and to unravel complex petrologic histories of deeply subducted material (Bebout and Nakamura, 2003). White mica is also an important boron reservoir in subduction zone rocks at depths of between 15 and $45 \mathrm{~km}$ with concentrations of up to $\sim 5500 \mathrm{ppm} \mathrm{B}$ (Domanik et al., 1993; Bebout et al., 2007; Menold et al., 2016; Sievers et al., 2016), which dominates the boron budget within the slab even in the presence of tourmaline (Leeman and Sisson, 1996; Klemme et al., 2011). In island arc environments (Japan), ${ }^{11} \mathrm{~B}$ is preferentially enriched progressively depleted in the heavy ${ }^{11} \mathrm{~B}$ with distance from the subduction front (Ishikawa and Nakamura, 1994). Thus, boron concentrations and $\delta^{11} \mathrm{~B}$ in subduction settings can provide insights into the slab transfer mechanisms of dehydration reactions and/or partial melting reactions (e.g., Peacock and Hervig, 1999; Benton et al., 2001; Scambelluri and Tonarini, 2012; Harvey et al., 2014; Konrad-Schmolke and Halama, 2014; Palmer, 2017; De Hoog and Savov, 2018). Boron also can reach concentrations of several weight percent of $\mathrm{B}_{2} \mathrm{O}_{3}$ in S-type granites and late silicate intrusions (Pichavant et al., 1988; Kowalski and Wunder, 2018; London, 1997; Thomas et al., 2003). Hence, knowledge of boron partitioning and isotope fractionation during magma hydrothermal evolution can aid in understanding granite petrogenesis. 
In igneous and hydrothermal systems, boron occurs almost exclusively in either trigonal or tetrahedral coordination with oxygen. In terms of isotope partitioning, ${ }^{11} \mathrm{~B}$ favors trigonal coordination and ${ }^{10} \mathrm{~B}$ tetrahedral coordination (Kakihana et al., 1977), because of the preferential partitioning of light isotopes into phases with higher coordination and longer $\mathrm{B}-\mathrm{O}$ bonds (Hawthorne et al., 1996; Wunder et al., 2005). Thus, knowledge of the coordination of boron in interacting phases (i.e., fluids, minerals, and melts) is essential for a first-order quantification of boron isotope fractionation among these phases. At P-T conditions corresponding to those near the Earth's surface, the nature of the dominant boron species in hydrous fluids is strongly dependent on $\mathrm{pH}$ (Palmer and Swihart, 1996), with $\mathrm{B}(\mathrm{OH})_{4}{ }^{-}$ dominating at high $\mathrm{pH}$ and $\mathrm{B}(\mathrm{OH})_{3}$ dominating in neutral and acidic hydrous fluids. Experiments have shown that this $\mathrm{pH}$ dependence also holds true for high pressure and temperature (Schmidt et al., 2005).

The boron isotope fractionation factors between tourmaline and white mica measured in natural samples (Klemme et al., 2011) are larger than those estimated from the in-situ experimental data of Meyer et al. (2008) and Wunder et al. (2005). In a theoretical study, Kowalski et al. (2013) interpreted that the discrepancy most likely arises from the presence of $\mathrm{B}(\mathrm{OH}){ }_{4}{ }^{-}$species in the neutral solutions, which has been observed in the experiments of Schmidt et al. (2005). Hervig et al. (2002) determined the boron isotope fractionation between silicate melts and aqueous fluids experimentally. They attributed the observed large boron isotope fractionation (e.g., $-7.1 \%$ at $750{ }^{\circ} \mathrm{C}$ ) to the dominance of $\mathrm{BO}_{4}$ in the melt (Hervig et al., 2002). However, a later spectroscopic study suggests that boron is present predominantly as $\mathrm{BO}_{3}$ in rhyolite melts (Tonarini et al., 2003).

Silicate melts are structurally more complex than crystals, because of their more disordered nature and variable chemical compositions. The proportions of 3- and 4-fold coordinated boron in silicate melts and glasses are controlled by a combination of chemical composition, 
temperature and pressure (Kowalski and Wunder, 2018). For example, the average boron coordination number in boron-silicate melts depends on the $\mathrm{SiO}_{2} / \mathrm{B}_{2} \mathrm{O}_{3}$ ratios and the alkali oxide/ $\mathrm{B}_{2} \mathrm{O}_{3}$ ratios (Dell et al., 1983; Geisinger et al., 1988; Dingwell et al., 1996; Manara et al., 2009), such that the maximum BO4 proportion in alkali borate melts occurs at alkali oxide concentrations of $35 \mathrm{~mol} \%$. The addition of $\mathrm{SiO}_{2}$ increases the proportion of $\mathrm{BO}_{4}$ in alkali boron-silicate melts, whereas the presence of aluminum destabilizes boron in tetrahedral coordination. Interaction between water and melt also affects the structure of aluminosilicate melts (Mysen, 2010) and stabilizes $\mathrm{BO}_{4}$ in albite glass (Schmidt et al., 2004), because an increase in the fraction of water dissolved as hydroxyl groups, leads to the formation of B-OH complexes in the melt (Dingwell et al., 1996). In addition to the chemical composition, the effects of temperature (e.g., Smirnov et al., 2005; Manara et al., 2009; Wu and Stebbins, 2010, 2013) and pressure (e.g., Schmidt et al., 2004; Edwards et al., 2014) on boron coordinated structures are considerable. The forward reaction $\left[\mathrm{BO}_{4}\right] \Leftrightarrow\left[\mathrm{BO}_{3}\right]+\mathrm{NBO}(\mathrm{NBO}$ represents the non-bridging oxygen) is favored by increasing temperature and decreasing pressure (Wu and Stebbins, 2010, 2013). For alkali borosilicate melts (e.g., $10 \mathrm{~B}_{2} \mathrm{O}_{3} \cdot 30 \mathrm{Na}_{2} \mathrm{O} \cdot 60 \mathrm{SiO}_{2}$ and $\left.10 \mathrm{~B}_{2} \mathrm{O}_{3} \cdot 15 \mathrm{Na}_{2} \mathrm{O} \cdot 15 \mathrm{CaO} \cdot 60 \mathrm{SiO}_{2}\right)$, the fraction of tetrahedral boron drops from 0.7 in the glass to 0.3 in the trigonal $\mathrm{BO}_{3}$ to tetrahedral $\mathrm{BO}_{4}$ likely proceeds via a trigonal pyramid precursor phase (Edwards et al., 2014). Generally, conditions of higher pressure and lower temperature help stabilize $\mathrm{BO}_{4}$ units in melts and glass. In addition, the $\mathrm{BO}_{4}$ proportion in the melt can be affected by the cooling rate, the field strength of metallic elements (Wu and Stebbins, 2010, 2013), and carbonate assimilation by the magma (Deegan et al., 2016). All these observations demonstrate that understanding the behavior of boron-coordinated structures in natural melt systems is challenging, particularly if coupled with the variable partitioning of boron between aqueous and melt phases. For example, whereas the aqueous fluid/melt partition coefficient 
ranges from $0.33-0.54$ for basaltic melts to 1.2 for rhyolite melt (Hervig et al., 2002; Schatz et al., 2004), it reaches 4.6 between aqueous vapor and melt (Schatz et al., 2004).

Recently, considerable progress has been made in modeling the equilibrium fractionations of stable isotopes among different phases (Schauble, 2004; Schauble et al., 2009; Blanchard et al., 2017). Examples include, hydrogen isotope fractionation between hydrous minerals and water (M'eheut et al., 2010), oxygen and silicon isotope fractionation among silicate minerals (M'eheut et al., 2007, 2009; M’eheut and Schauble, 2014; Huang et al., 2014), oxygen isotope fractionation among hydroxyl-bearing silicates, anhydrous silicate minerals, magnetite, apatite, carbonate and sulfate minerals and between hydroxide minerals and water (Zheng, 1993a, 1993b; Zheng, 1995; Zheng, 1996; Zheng, 1998; Zheng, 1999; Zheng et al., 1998), chlorine isotope fractionation in Cl-bearing molecules and metal chlorides (Schauble et al., 2003; Balan et al., 2019), sulfur isotope fractionation among sulfide and sulfate minerals, carbon isotope fractionation between carbonate magmas and minerals, boron, zinc and iron isotope fractionation between minerals and aqueous solutions (Schauble et al., 2001; Schauble, 2004; Hill and Schauble, 2008; Blanchard et al., 2009; Kowalski et al., 2013; Ducher et al., 2016, 2018; Balan et al., 2018; Li et al., 2020), as well as barium, magnesium and calcium isotope fractionation among silicate, oxide and carbonate minerals (Schauble, 2011; Pinilla et al., 2014; Huang et al., 2013, 2019; Antonelli et al., 2019; Mavromatis et al., 2020).

Theoretical studies using density functional theory (DFT) and ab initio molecular dynamics simulation (AIMD) satisfactorily explain for the dynamic effects on isotope fractionation in fluids (Rustad and Bylaska, 2007; Kowalski and Jahn, 2011; Kowalski et al., 2013; Kowalski and Wunder, 2018; Li et al., 2020). Modeling the behavior of molten silicates is crucial for our understanding of processes ranging from the cooling and crystallization of Earth's early magma ocean, to the generation and transport mechanisms of magma on modern day Earth (Solomatov, 2007). The diffusivity and viscosity control the mobility and rate of chemical reaction of 
silicate melts with their surroundings, so theoretical simulation of silicate melts using the firstprinciples molecular dynamics (FPMD) within the framework of density functional theory provides an essential tool to evaluate the physical properties of melts, including equations of state, thermodynamics, atomic and electronic structures, self-diffusion and viscosity etc. (Karki, 2010). Because natural silicate melts and silicate glasses are composed of networks of $\mathrm{SiO}_{4}$ polyhedra and secondary elements (such as $\mathrm{Mg}, \mathrm{Ca}$ and $\mathrm{Fe}$ ) are believed to diffuse through interstitial sites (Vashishta et al., 1990), the diffusion-induced isotope effect (DIE) in silicate melts has been investigated extensively through molecular dynamics (MD) simulations. For example, the thermal (Soret) effect and isotopic fractionation of $\mathrm{Mg}, \mathrm{Ca}$ and $\mathrm{Fe}$ in hightemperature silicate melts are well understood using the quantum-mechanical zero-point energy of diffusing species (Dominguez et al., 2011).

Owing to the cooperative motions of the many atoms involved in diffusion, significant diffusive fractionation of $\mathrm{Si}$ and $\mathrm{Mg}$ isotopes has been predicted to occur during magma mixing (e.g., the inter-diffusion between basaltic and rhyolitic magma is capable of producing isotope fractionations of tens of per mil in both $\mathrm{Si}$ and $\mathrm{Mg}$ ) and during crystallization (such as the growth of olivine phenocrysts) if the growth rate is fast (Goel et al., 2012). A comparison of the diffusion coefficients of $\mathrm{Mg}$ isotopes in $\mathrm{MgSiO}_{3}$ and $\mathrm{Mg}_{2} \mathrm{SiO}_{4}$ melts estimated from FPMD to the experimentally determined values in basalt-rhyolite melts suggested a dependence on the chemical composition of the melts (Liu et al., 2018; Richter et al., 2008). Thus, the DIE of Fe, $\mathrm{Mg}, \mathrm{Si}$ and $\mathrm{Li}$ in immiscible, ascending, silicate melts have been quantitatively predicted (Zhu et al., 2015). In addition to the dynamic properties, the MD studies of structural properties of melts have focused mainly on the two most important components $\left(\mathrm{MgO}\right.$ and $\left.\mathrm{SiO}_{2}\right)$ in silicate melts (Trave et al., 2002; Winkler et al., 2004; Pohlmann et al., 2004; Karki et al., 2006a, 2006b; Karki et al., 2007; Karki et al., 2009; Karki, 2010; De Koker et al., 2008; Martin et al., 2009; Vuilleumier et al., 2009). In contrast, it is assumed that the kinetic DIE of boron in 
silicate melts is insignificant at the temperature of melt-crystallization (Kowalski and Wunder, 2018), because of the low diffusivities of boron determined in haplogranite melts (Chakraborty et al., 1993). Whereas the major element concentrations of $\mathrm{SiO}_{2}, \mathrm{Al}_{2} \mathrm{O}_{3}, \mathrm{MgO}, \mathrm{CaO}, \mathrm{Na}_{2} \mathrm{O}$ and $\mathrm{K}_{2} \mathrm{O}$ are at a mol\% levels, the content of boron is in ppm levels in natural silicate melts. Considering the relatively low abundance of boron and the high variability of the $\mathrm{BO}_{3} / \mathrm{BO}_{4}$ ratio in silicate melts due to factors that include thermodynamic conditions (PT), the chemical compositions, the field strength of metallic elements, the cooling rate, as well as chemical reactions (carbonate assimilation, fluid exsolution etc.), the equilibrium isotope fractionation of the trace boron in melts may be better represented by the energetic differences in the respective bonding environments. This approach involves developing an appropriate model to represent boron structural units in a silicate melt network, and to acquire all the vibrational frequencies for boron species in the melt, especially at high P-T conditions.

In general, a simplified treatment can be adopted based on the observation that vibrational frequencies in many strongly-bonded molecule-like species are not sensitive to the environment of the phase in which they occur (Schauble, 2004). For example, Kakihana et al. (1977) proposed a simplified approach for the first approximation of the reduced partition function ratios (RPFRs) of polynuclear borate anions containing $\mathrm{BO}_{3}$ and $\mathrm{BO}_{4}$ units, in which the boron sites within the polynuclear species are considered to be present as the isolated monomeric units, $\mathrm{B}(\mathrm{OH})_{3}$ and $\mathrm{B}(\mathrm{OH})_{4}{ }^{-}$. Oi et al. (1989) then calculated the RPFRs of polyborate anions in boron-bearing minerals with an extension of the rule of the geometric average of the RPFRs of aqueous $\mathrm{B}(\mathrm{OH})_{3}$ and $\mathrm{B}(\mathrm{OH})_{4}{ }^{-}$. This formulation was used to predict the difference in boron isotope composition between different borate minerals forming from similar fluids (Palmer and Helvaci, 1997). However, an inconsistency between the theoretical predictions and experimental data from natural silicate melt and minerals was observed by Tonarini et al. (2003) using the same approach. These authors concluded that the reduced 
partition function ratios (RPFRs) assigned for $\mathrm{B}(\mathrm{OH})_{3}$ and $\mathrm{B}(\mathrm{OH})_{4}^{-}$species in aqueous solutions by Kakihana et al. (1977) may not be appropriate for $\mathrm{BO}_{3}$ and $\mathrm{BO}_{4}$ units in silicate melt/glass structures (Tonarini et al., 2003). The inconsistency likely reflects the complex structures of aluminous-silicate melts, in which the $\mathrm{BO}_{3}$ and $\mathrm{BO}_{4}$ units exist in a number of different site arrangement, forming complex structural units with the silicon and aluminum polyhedra in the melt network.

Granitic melts are the most common natural silicate melts in the continental crust and typically contain $>65 \mathrm{wt} \% \mathrm{SiO}_{2}$ and $\sim 15 \mathrm{wt} \% \mathrm{Al}_{2} \mathrm{O}_{3}$. Previous computational modeling of natural rhyolite melts $\left(84 \mathrm{~mol} \% \mathrm{SiO}_{2}\right.$ and $\left.8 \mathrm{~mol} \% \mathrm{Al}_{2} \mathrm{O}_{3}\right)$ shows that $\left[\mathrm{SiO}_{4}\right]^{4-}\left({ }^{[4]} \mathrm{Si}\right)$ and $\left[\mathrm{AlO}_{4}\right]^{5-}$ $\left({ }^{[4]} \mathrm{Al}\right)$ are the most common coordination structures (Vuilleumier et al., 2009). Theoretical calculation for liquid $\mathrm{SiO}_{2}$ also shows that ${ }^{[4]} \mathrm{Si}$ is generally the dominant structure and that $\left[\mathrm{SiO}_{5}\right]^{6-}\left({ }^{[5]} \mathrm{Si}\right)$ and $\left[\mathrm{SiO}_{6}\right]^{8-}\left({ }^{[6]} \mathrm{Si}\right)$ only become important at higher pressure (e.g., 7 and 20 GPa) (Rustad et al., 1990; Vuilleumier et al., 2009). In borosilicate melts and glasses, the $\mathrm{BO}_{3}$ and $\mathrm{BO}_{4}$ units (quasi-planar trigonal $\left[\mathrm{BO}_{3}\right]^{3-}$ and tetrahedral $\left[\mathrm{BO}_{4}\right]^{5-}$ ) can form numerous combinations with network-forming components of $\left[\mathrm{SiO}_{4}\right]^{4-}$ and $\left[\mathrm{AlO}_{4}\right]^{5-}$ (Kowalski and Wunder, 2018). Similarly, $\left[\mathrm{BO}_{4}\right]^{5-}$ in white mica and $\left[\mathrm{BO}_{3}\right]^{3-}$ in tourmaline form networks with $\left[\mathrm{SiO}_{4}\right]^{4-}$ and $\left[\mathrm{AlO}_{6}\right]^{9-}$. Because the $\mathrm{B}-\mathrm{O}$ bond is stronger than $\mathrm{Si}-\mathrm{O}$ and $\mathrm{Al}-\mathrm{O}$ bonds (Navrotsky, 1996), and B-O interactions may overwhelm the effect of next-nearest neighbors, changes in bulk chemistry have a relatively minor impact on boron isotope fractionation (Hervig et al., 2002). Hence, a local structure containing next-nearest neighbor atoms is sufficient to include all the significant effects of networks on boron isotope fractionation (Liu and Tossell, 2005; Li et al., 2020).

To the best of our knowledge, there is still no consensus on the precise coordination structures of boron in silicate melts, which limits the interpretation of boron isotope fractionation during the evolution of magmatic-hydrothermal fluids. In this study, the $\mathrm{BO}_{3}$ unit and the $\mathrm{BO}_{4}$ unit of 
silicate melts are represented using cluster models with variable chemical compositions. The aim of this approach is to calculate equilibrium boron isotope fractionation factors among boron-rich silicate minerals, melts and fluids. As an example, the model is used here to examine the boron isotopic composition of magmas prior to phase separation and assess the applicability of the white mica-tourmaline geothermometers in magmatic-hydrothermal ore-forming systems.

\section{Calculation methods}

\subsection{Models for white mica minerals}

The models for tourmaline and aqueous fluids were described in detail in our previous study (Li et al., 2020). Periodic boundary cell (PBC) models for seven white micas were constructed based on the boromuscovite structure (Liang et al., 1995). These models were constructed with different variables (polytype, lattice parameters, chemical composition, and the B/Si orderings) in order to examine the effect of individual variable on boron isotopes fractionation (Table 1,

Fig. 1). The PBC models of boromuscovite and phengite were constructed in the Material Studio Materials Visualizer module (Accelrys, Inc., version 7.0) and the original cell volume was maintained with slight changes in the original cell parameters after atomic substitution in crystal lattices. All white mica models were optimized with fixed cell parameters.

\subsection{Cluster models for silicate melts}

The $\mathrm{BO}_{3}$ and $\mathrm{BO}_{4}$ units of silicate melts are represented using cluster models with variable chemical compositions (Fig. 2). The clusters for the $\mathrm{BO}_{3}$ unit were constructed with reference to the tourmaline structure, with different major elements (e.g., $\mathrm{Mg}$ in $\mathrm{BO}_{3}-i, \mathrm{Mg}, \mathrm{Fe}$ in $\mathrm{BO}_{3}-j$, $\mathrm{F}$ in $\mathrm{BO}_{3}-k, \mathrm{Ca}, \mathrm{Li}$ in $\mathrm{BO}_{3}-l, \mathrm{Mg}, \mathrm{Al}$ in $\mathrm{BO}_{3}-m, \mathrm{Al}$ in $\mathrm{BO}_{3}-n, \mathrm{Fe}$ in $\mathrm{BO}_{3}-o$ and $\mathrm{Fe}, \mathrm{Mg}$ in $\mathrm{BO}_{3}-$ $p$ ). The clusters for the $\mathrm{BO}_{4}$ unit were constructed on the basis of the crystal structure of phyllosilicate minerals (e.g., muscovite, biotite, phlogopite and serpentine), in which different 
chemical compositions were considered $\left({ }^{[6]} \mathrm{Al}\right.$ in $\mathrm{BO}_{4-i},{ }^{[4]} \mathrm{Si}$ in $\mathrm{BO}_{4-j}$ and $\mathrm{BO}_{4-} k,{ }^{[4]} \mathrm{Al}$ in $\mathrm{BO}_{4-}$ $l,{ }^{[6]} \mathrm{Fe}$ in $\mathrm{BO}_{4}-m,{ }^{[6]} \mathrm{Mg}$ in $\left.\mathrm{BO}_{4}-n\right)$.

\subsection{Calculation of the reduced partition function ratio (RPFR)}

The vibrational frequency shifts resulting from isotopic substitution can lead to equilibrium isotope fractionation (Bigeleisen and Mayer, 1947; Urey, 1947). The reduced partition function ratio (i.e., $\mathrm{RPFR}(\mathrm{A})$ ) of element $\mathrm{X}$ between phase $\mathrm{A}$ and an ideal gas of $\mathrm{X}$ atoms can be expressed in the harmonic approximation (Li et al., 2019):

$\operatorname{RPFR}(A)=\frac{Q^{*}}{Q}=\prod_{i}^{N_{m}} \frac{u_{i}^{*}}{u_{i}} \frac{\exp \left(-u_{i}^{*} / 2\right)}{1-\exp \left(-u_{i}^{*}\right)} \frac{1-\exp \left(-u_{i}\right)}{\exp \left(-u_{i} / 2\right)}$

where * represents the heavier isotope; $Q^{*}$ and $Q$ refer to the vibrational partition function for the heavy and light isotopes, respectively; $i$ is the index of vibration modes; $\mathrm{Nm}$ represents the number of vibration modes. For convenience, we use the relationship $\beta=\mathrm{RPFR}^{1 / n}$, in which the exponent of $1 / n$ is a normalizing factor to accounts for multiple substitutions in phase A containing more than one atom of X (Schauble, 2004). The term of $u_{i}$ was calculated by:

$u_{i}=\frac{h v_{i}}{k T}$

where $h$ and $k$ are Plank's and Boltzmann's constants, respectively; $T$ is temperature in degrees Kelvins; $v_{i}$ is the vibration frequency of the $i$ th mode. The isotope fractionation at equilibrium between phase A and B can be expressed as (Wang et al., 2019; Li et al., 2019):

$$
\Delta_{A-B} \approx 1000 \ln \alpha_{A-B}=1000 \ln \beta_{A}-1000 \ln \beta_{B}
$$

Calculation details for the reduced partition function ratio of tourmaline and aqueous fluids were provided in $\mathrm{Li}$ et al. (2020). In the current study, the cluster models of $\mathrm{BO}_{3}$ and $\mathrm{BO}_{4}$ units were calculated using the B3LYP exchange-correlation functional with 6-31G(d) basis set using the GAUSSIAN 16 software package (Frisch et al., 2016). All the calculations for white micas were carried out using the Cambridge Serial Total Energy Package (CASTEP) in Material Studio 7.0 (Clark et al., 2005). The Perdew-Burke-Ernzerhof (PBE) exchange- 
correlation functional and the norm-conserving pseudopotentials were employed in calculations of both the geometry optimization and the phonon frequency of the white mica models. The output parameters of k-points, cut-off energy, and q-points for 'Fine' quality level by Material Studio 7.0 are listed in Table 1 . To obtain more accurate frequencies, we use 0.9614 to scale the harmonic vibrational frequency of the cluster models. Application of this scaling factor for frequencies calculated with the combination of B3LYP functional and 6-31G(d) basis set, yields only minor overall root-mean-square errors between the fundamental and theoretical harmonic frequencies (Merrick et al., 2007). The $\beta$ values of the minerals, melts and fluids are listed in the Appendix (Table A1).

\subsection{Error estimation}

As emphasized by Kowalski and Wunder (2018), an important aspect of reliable theoretical predictions is an error estimation of the computed fractionation factors. Previous studies have indicated that the errors in the computed $\beta$ and $\Delta$ values could be estimated from an average error of vibrational frequencies (M'eheut et al., 2007; Kowalski and Jahn, 2011; Kowalski et al., 2013). Different functionals or more sophisticated and time-consuming post-Hartree-Fock methods, such as MP2, yield similar error estimates (Kowalski et al., 2013). The PBE calculations reproduce the frequencies with a systematic underestimation of 2 to $5 \%$ (M'eheut et al., 2007) and the BLYP functional systematically overestimates the harmonic frequencies by $3.5 \pm 1 \%$ (Kowalski et al., 2013). Consequently, the $\beta$ and $\Delta$ values are systematically overestimated by $7.0 \pm 2 \%$ with the BLYP functional (Kowalski and Wunder, 2018). The consistency in the error estimations for $\beta$ and $\Delta$ values between minerals and fluid from Kowalski et al. (2013) and Li et al. (2020) shows the robustness of the error estimation scheme proposed by Kowalski et al. (2013). It is noteworthy that in the error estimation method of M'eheut et al. (2009), a systematic error of $n \%$ on the phonon frequencies can induce a relative error on the $\ln \beta$ factors of $n \%$ (at low temperatures) and $2 n \%$ (at high temperature). Hence, we 
estimate that the relative error in $\ln \beta$ factors induced by DFT or anharmonicity should not exceed $1.5 n \%$ (about $5 \%$ in $\ln \beta$ ). The overall absolute errors for $1000 \ln \beta$ and $1000 \ln \alpha$ in $\%$ are estimated by the relationships of $[1000 \ln \beta \times 596] / 2$ and $[(1000 \ln \beta A+1000 \ln \beta B) \times 596] / 2$ respectively.

\section{Results}

\section{1. $\beta$ factors of white mica with variable B/Si ordering and chemical compositions}

From the 56 types of muscovite structures given in the American Mineralogist crystal structure database (Downs and Hall-Wallace, 2003), each tetrahedron contains approximately 0.75 Si and $0.25 \mathrm{Al}$ in muscovite $\left(\mathrm{KAl}_{2}\left[\mathrm{AlSi}_{3} \mathrm{O}_{10}\right](\mathrm{OH})_{2}\right)$, with a disordered $\mathrm{Al} / \mathrm{Si}$ arrangement in the tetrahedral layer. Because of the reduction in the bond length from $1.64 \AA$ for $(\mathrm{Si}, \mathrm{Al})-\mathrm{O}$ in albite to $1.47 \AA$ for $\mathrm{B}-\mathrm{O}$ in reedmergnerite, a disordered structure is more favorable than an ordered structure for the substitution of B for $\mathrm{Al}$ (Christ, 1965). In the boromuscovite structure $\left(\mathrm{KAl}_{2}\left[\mathrm{BSi}_{3} \mathrm{O}_{10}\right](\mathrm{OH})_{2}\right)$ defined by Liang et al. (1995), each tetrahedral position also contains approximately $0.75 \mathrm{Si}$ and $0.25 \mathrm{~B}$, when ${ }^{[4]} \mathrm{Al}$ is replaced by $\mathrm{B}$ in muscovite. Because ${ }^{[4]} \mathrm{B}-\mathrm{O}-$ ${ }^{[4]} \mathrm{B}$ linkages are relatively unfavorable energetically as are ${ }^{[4]} \mathrm{Al}-\mathrm{O}-{ }^{[4]} \mathrm{Al}$ linkages in aluminosilicates (Du et al., 2004), the possible distributions of boron and silicon can be represented by two arrangements of boron atoms in the B-Si tetrahedral layer in white mica models: 1) Type-I, which contains one or two boron atoms in any six-membered ring of the layer; and 2) Type-II, in which the arrangement comprises three boron atoms in any sixmembered ring of the B-Si tetrahedral layer (as illustrated in the inset of Fig. 1 and 3a). Given the variety of polytypes, lattice parameters, chemical compositions, and the $\mathrm{B} / \mathrm{Si}$ orderings in the tetrahedral layer of white mica, five models for boromuscovite and two models for phengite were constructed in this study (Fig. 1). The minerals, boromuscovite-A-2 M1, boromuscoviteA-1 M, phengite-A-2 M1 and phengite-B-2 M1 have Type-I arrangements of boron atoms, 
whereas boromuscovite-B-1 M, boromuscovite-B-2 M1 and boromuscovite-C-2 M1 have Type-II arrangements. The calculated $\beta$ factors for the boromuscovite models in Fig. 3 reveal that polytypes of the same minerals (e.g., boromuscovite-B-1 M and boromuscovite-B-2 M1) have very similar $\beta$ factors at $600 \mathrm{~K}$, with a difference of $\leq 1 \%$ o between this study with the PBE functional and Kowalski et al. (2013) with the BLYP functional (Fig. 3a). This observation suggests that the effect of the orientation of $\mathrm{OH}^{-}$groups in the inter-layers on boron isotope fractionation is insignificant. In addition, phengite-A-2 M1 and phengite-B-2 M1, which have the same lattice parameters and are of the same polytype, but differ in chemical composition (replacement of Si by $\mathrm{Al}$ in a six-membered ring of the $\mathrm{B}-\mathrm{Si}$ tetrahedral layer), have similar $\beta$ factors $(0.39 \%$ at $600 \mathrm{~K}$; Fig. 3a). With the same B/Si ordering, the differences of $\beta$ factors are less than $1.2 \%$ for Type-I white mica and $0.83 \%$ for Type-II white mica at $600 \mathrm{~K}$ (Fig. 3a). By contrast, boromuscovite-A-1 M (Type-I) and boromuscovite-B-1 M (Type-II) share the same polytype and chemical composition, but differ more in their $\beta$ factors $(2.5 \%$ at $600 \mathrm{~K}$; Fig. 3a). Similarly, the $\beta$ factor of boromuscovite-C-2 M1 (Type-II) differs from those of phengite-A-2 M1 (Type-I) and phengite-B-2 M1 (Type-I) (which share the same lattice parameters and polytypes) by as much as $3.5-3.9 \%$ at $600 \mathrm{~K}$. Therefore, the differences in the B/Si ordering (i.e., Type-I and Type-II white micas) may cause obvious changes in $\beta$ factors (average $2.9 \%$ at $600 \mathrm{~K}$ ). The consistency in the above behavior suggests that the $\mathrm{B} / \mathrm{Si}$ ordering in the inter-layers and in the $\mathrm{B}-\mathrm{Si}$ tetrahedral layer is more important in controlling the boron isotope fractionation than other factors, such as chemical compositions and polytype differences. The driving force behind the phenomena is considered to be the $\mathrm{B}-\mathrm{O}$ bond length (Kowalski et al., 2013), where a longer B-O bond leads to a smaller $\beta$ factor $(1.53 \pm 0.05 \AA$ for Type-I and $1.58 \pm 0.02 \AA$ for Type-II).

As shown in Fig. A1, the difference in $\beta$ factors of tourmaline calculated with the PBE, B3LYP functional (Li et al., 2020) and the BLYP functional (Kowalski et al., 2013) are $\sim \pm 0.5 \%$ at 
$1000 \mathrm{~K}$ and $\sim \pm 1.0 \%$ at $600 \mathrm{~K}$, reflecting the negligible differences in the $\beta$ factors of minerals obtained using different exchange-correlation functionals. In contrast, the $\beta$ factors with Type I and Type II of white mica determined in this study are $\sim 5 \%$ and $\sim 1 \%$ larger than those of Kowalski et al. (2013) at $\sim 600 \mathrm{~K}$, despite the consistency of the different boromuscovite-types in their cell volume and chemical composition. It is important to note, and this study) used cell parameters that lie well within the wide range observed in natural white micas as a consequence of isomorphous substitutions (e.g., Deer et al., 2013). Hence, any discrepancies between the results from this study and those of Kowalski et al. (2013) may be mirrored in natural systems, due to the $\mathrm{B} / \mathrm{Si}$ ordering diversity in the tetrahedral layer of white mica minerals.

In addition to the $\mathrm{B} / \mathrm{Si}$ ordering, the sole influence from the chemical compositions of mica minerals on $\beta$ factors has been evaluated. This evaluation indicates that the differences in $1000 \ln \beta$ are $<1.2 \%$ for boromuscovite and phengite (type I), and $<0.8 \%$ for mica fragments with variable chemical compositions at $600 \mathrm{~K}$ (Fig. 3b). Taken in combination with the small difference $(<1.8 \%$ ) in $1000 \ln \beta$ for tourmaline group minerals at $600 \mathrm{~K}$ (Li et al., 2020), it appears that the chemical composition of boron bearing minerals has a minor effect on the $\beta$ factor.

\section{2. $\beta$ factors of melts and fluids with variable proportion of $\mathrm{BO}_{4}$}

As stressed above, the proportions of $\mathrm{BO}_{3}$ and $\mathrm{BO}_{4}$ are highly variable in both melt and fluid. The temperature-dependent $\beta$ values of silicate melt and aqueous fluid are shown in Fig. 4 for temperatures $>600 \mathrm{~K}$. The large difference in the $\beta$ values of silicate melt and aqueous fluid with variable $\mathrm{BO}_{3}$ and $\mathrm{BO}_{4}$ demonstrates that an understanding of the coordination of boron in the interacting phases (i.e., fluids, minerals, and melts) is essential for a first-order quantification of boron isotope fractionation in natural systems. The dataset of $\beta$ factors is given in the Appendix (Table A2). 


\section{Discussion}

\subsection{Boron isotope fractionation between white mica and aqueous liquid}

The calculated boron isotope fractionation factors $(1000 \ln \alpha)$ between white mica (only including $\mathrm{BO}_{4}$ ) and aqueous liquid are shown in Fig. 5. In general, the value of 1000lnamicafluid for an acidic fluid is larger than for a basic fluid, based on the similarity of the results of this study to those of Kowalski et al. (2013). The temperature dependence of boron isotope fractionation in the range of $600 \mathrm{~K}$ to $1000 \mathrm{~K}$ for a basic fluid (largely tetrahedral boron coordination) is described by the equation $1000 \ln \alpha_{\text {mica-basic fluid }}=0.8-2.4 \times(1000 / \mathrm{T})-0.8 \times$ $(1000 / \mathrm{T})^{2}$ and for an acidic liquid (largely trigonal boron coordination) by the equation $1000 \ln \alpha_{\text {mica-acidic fluid }}=7.0-14.0 \times(1000 / \mathrm{T})-1.2 \times(1000 / \mathrm{T})^{2}$. As the amount of fluid phase in the run products was too low to determine $\mathrm{pH}$ in the fluid after the run, accurate $\mathrm{pH}$ values and the proportions of $\mathrm{B}(\mathrm{OH})_{3}$ and $\mathrm{B}(\mathrm{OH})_{4}{ }^{-}$in fluids are not available for the experiments of Wunder et al. (2005). Our theoretical calculations, however, suggest that there was $\sim 10 \%$ $\mathrm{B}(\mathrm{OH})_{3}$ in the basic fluid and $\sim 33 \% \mathrm{~B}(\mathrm{OH})_{4}{ }^{-}$in the weakly acidic fluid in experimental investigation of boron isotope fractionation between white mica and fluids (Wunder et al., 2005). Given the large effect of $\mathrm{pH}$ on the boron speciation, it is therefore important, in comparing experimental determinations of boron isotope fractionation with theoretical estimates, to correct ambient temperature measurements to the in-situ $\mathrm{pH}$. The Raman spectra indicate that the relative proportions of $\mathrm{B}(\mathrm{OH})_{3}$ and $\mathrm{B}(\mathrm{OH})_{4}{ }^{-}$in fluids depends not only on $\mathrm{pH}$, but also varies with temperature and pressure at high P-T conditions (Schmidt et al., 2005). The recent study of Hansen et al. (2017) confirmed that in-situ pH values under hydrothermal conditions are different from those measured at $25{ }^{\circ} \mathrm{C}$. Therefore, in-situ $\mathrm{pH}$ variations should be taken into account to predict boron speciation in hydrothermal fluids.

\subsection{Boron isotope fractionation between coexisting white mica and tourmaline}


Based on the discussion above, boron isotope fractionation between minerals is likely dependent on both the coordination of the boron and the $\mathrm{B} / \mathrm{Si}$ orderings within the minerals. For white mica and tourmaline, there is a good agreement among the theoretical, empirical and corrected experimental results (Fig. 6). The overall temperature dependence of boron isotope fractionation between tourmaline and white mica in the range $600 \mathrm{~K}$ to $1000 \mathrm{~K}$ was fitted by the equation of $1000 \ln \alpha_{\text {mica-tur }}=1.9-5.4 \times(1000 / \mathrm{T})-3.4 \times(1000 / \mathrm{T})^{2}$ after taking the variation in the chemical compositions and the $\mathrm{B} / \mathrm{Si}$ orderings of the minerals into account (i.e., Type-I and Type-II white micas). The minor discrepancies that remain between the theoretical predications and experimental determinations (Klemme et al., 2011; Belley et al., 2014; Kutzschbach et al., 2016; Cao et al., 2018) may be due to heterogeneities in the chemical composition (especially for natural zoned tourmaline) (Li et al., 2020) and the local atomic environment (especially for the $\mathrm{B} / \mathrm{Si}$ orderings in the $\mathrm{B}-\mathrm{Si}$ tetrahedral layers of white mica). Another factor may be the growth history of the minerals. For example, there is a ca. $4 \%$ offset for one $\Delta_{\text {mica-tur }}$ value of the dravite-phengite pairs from Syros (Greece) with retrograde growthhistories summarized by Klemme et al. (2011) (Fig. 6). This exceeds the compositional effect on boron isotope fractionation of tourmaline and mica (i.e., about $1.2 \%$ at $400-430{ }^{\circ} \mathrm{C}$, Li et al., 2020) and may result from retrograde overprinting of $\delta^{11} \mathrm{~B}$ in tourmaline or mica. The overall consistency between the two individual theoretical studies (Kowalski et al., 2013 and this study) and the experimental/empirical data strongly supports the hypothesis that boron coordination plays a key role in controlling isotope fractionation among coexisting minerals under equilibrium condition. In addition, this study emphasizes that the local heterogeneity in the $\delta^{11} \mathrm{~B}$ of white mica is mainly due to the $\mathrm{B} / \mathrm{Si}$ disorder in the tetrahedral layer rather than the differences in chemical compositions.

\subsection{Comparison of measured and calculated $\alpha$ factors in mineral-melt and fluid-melt systems}


Prior to discussion of the boron isotope fractionation in systems that contain complex silicate melts, the applicability of a simplified treatment of boron coordination structures in silicate melts is assessed by comparing of the theoretical and experimental data. Tonarini et al. (2003) experimentally determined the proportion of $\mathrm{BO}_{4}$ (i.e., $\mathrm{R}\left(\mathrm{BO}_{4}\right)$ ) of volcanic glass (liquid) in equilibrium with biotite from the Roccastrada, Mt. Amiata and Mt. Cimini (Italy) to be $8 \%$ at $1028-1093 \mathrm{~K}, 15 \%$ at $1023-1073 \mathrm{~K}$ and $26 \%$ at $1123-1153 \mathrm{~K}$, respectively. With the known parameters of $\mathrm{R}\left(\mathrm{BO}_{4}\right)$ and $\mathrm{T}$, the calculated boron isotope fractionation factors between silicate melts and white micas are compared with the measured values in Fig. 7a. The calculated boron isotope fractionations are consistent with the measured values for samples from Roccastrada and Mt. Amiata. For the Mt. Cimini sample, the theoretically predicted $\Delta^{11} \mathrm{~B}_{\text {melt-mica }}$ ranges from $4.6 \pm 0.8 \%$ o to $4.3 \pm 0.7 \%$ in the temperature range 1123 to $1153 \mathrm{~K}$, and is greater than the measured boron isotope fractionation value of $2.8 \pm 0.8 \%$. One explanation for this difference may be that the crystallization temperature of the Mt. Cimini sample is less well-constrained than for the other samples (Tonarini et al., 2003). Alternatively, the silicate melt may have undergone fluid exsolution after the mica crystallization. This would have led to the measured

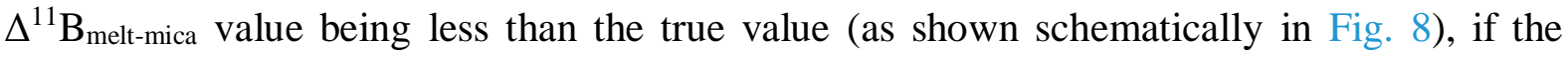
temperature estimate of the Mt. Cimini sample is reliable. Because boron partitions preferentially into aqueous liquid-like supercritical fluids as $\mathrm{BO}_{3}$ (London et al., 1988), the $\mathrm{R}\left(\mathrm{BO}_{4}\right)$ of the residual melt increases, which lowers the $\delta^{11} \mathrm{~B}$ in the melt. In the case of Mt. Cimini, the $\delta^{11} \mathrm{~B}$ measured in the glass may therefore not represent the boron isotopic composition of the initial melt from which the biotite crystallized, but rather a degassed melt. After correcting the boron isotope fractionation between the final melt and biotite in the Mt. Cimini sample with the boron isotope fractionation factor $\left(\Delta^{11} \mathrm{~B}_{\text {melt-fluid }}\right)$ of $-1.7 \pm 0.9 \%$ and $1.8 \pm 0.9 \%$ during fluid exsolution at $1153 \mathrm{~K}$ and $1123 \mathrm{~K}$, the $\Delta^{11} \mathrm{~B}_{\text {initial melt-mica }}$ is $4.5 \pm 0.8 \%$ o 
$\left(\Delta^{11} \mathrm{~B}_{\text {melt-mica corrected }}=\Delta \Delta^{11} \mathrm{~B}_{\text {melt-mica measured }}-\Delta^{11} \mathrm{~B}_{\text {melt-fluid predicted }}\right)$, which is close to the theoretically predicted value (Fig. 7a).

In contrast to the case of Mt. Cimini, a study of quartz-hosted melt inclusions and degassed glassy groundmass of the Long Valley rhyolite revealed that aqueous phase separation did not affect the isotope composition of the melt; i.e., the melt inclusions and the degassed glass had the same boron isotopic composition (Schmitt and Simon, 2004). This conclusion is supported by other studies of volcanic suites in which strong positive correlations were observed between the concentrations of boron and immobile incompatible elements (e.g., $\mathrm{Nb}, \mathrm{Be}, \mathrm{La}, \mathrm{Zr}$ ), implying that boron losses from magma by volatile exsolution are small (Ryan and Leeman, 1996; Tonarini et al., 2004). The differences in the behavior between the magmatic systems discussed above may relate to their boron concentrations; the Long Valley rhyolites contain $<70$ ppm boron (Schmitt and Simon, 2004), whereas the Mt. Cimini glasses contain >500 ppm boron (Tonarini et al., 2003). At higher boron concentrations, boron may exceed the buffering capacity of the melt and be more strongly partitioned into the aqueous phase and thus potentially be lost from the melt during volatile exsolution (London et al., 1996; Dingwell et al., 1996).

Boron isotope fractionation between silicate melts and fluids in the temperature range $1023 \mathrm{~K}$ to $1373 \mathrm{~K}$ has been determined experimentally by Hervig et al. (2002). It was assumed that the trace boron dissolved in fluids is predominantly in trigonal coordination, whereas that in the silicate melts is predominantly tetrahedral (Hervig et al., 2002). A systematical investigation of the partitioning and isotope fractionation of boron between granitic melt and aqueous solution at 973 and $1073 \mathrm{~K}$ and $0.2 \mathrm{GPa}$ concurred that the fraction of tetrahedral $\mathrm{BO}_{4}$ coordination in hydrous granitic melt is considerable (Maner and London, 2018). Consequently, we calculated the $\beta$ factors of silicate melt models with variable $\mathrm{R}\left(\mathrm{BO}_{4}\right)$ varying from 0.5 to 1 at the different temperatures. The theoretical estimates of boron isotope 
fractionation factors between silicate melts and fluids, made using the $\beta$ factors in fluids derived by extrapolating the theoretical lines of Li et al. (2020) and Kowalski et al. (2013), are generally in a good agreement with the experimental values of Hervig et al. (2002) and Maner and London (2018) (Fig. 7ab).

In addition, the theoretical estimates also show the dominant tetrahedral boron coordination in the melts, and allows the exact proportion of $\mathrm{BO}_{4}$ in each sample to be more tightly constrained. It is worth noting that, there is a $\sim 3 \%$ of difference in $\Delta^{11} \mathrm{~B}_{\text {melt-fluid values measured for the }}$ 'High B' and 'Low B' melts at $1073 \mathrm{~K}$ in the experiment by Maner and London (2018), and that the calculated $\Delta^{11} \mathrm{~B}_{\text {melt-fluid }}$ data are more consistent with the measured $\Delta^{11} \mathrm{~B}_{\text {melt-fluid }}$ values for the 'Low B' melt than the 'High B' melt, when assuming $\mathrm{R}\left(\mathrm{BO}_{4}\right)=1$ (Fig. 7b). Because it has been examined that the isotopic fractionation factors and partition coefficients reported in their study represent near-equilibrium values (Maner and London, 2018), the difference of

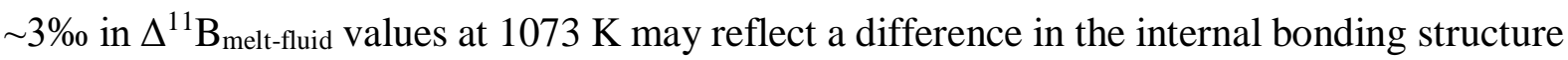
of boron in melts with different boron contents. Raman and NMR $\left({ }^{17} \mathrm{O},{ }^{27} \mathrm{Al},{ }^{29} \mathrm{Si}\right)$ spectra of albite glass $\left(\mathrm{NaAlSi}_{3} \mathrm{O}_{8}\right)$ with 4.8-16.7 wt \% $\mathrm{B}_{2} \mathrm{O}_{3}(14,880-51,770 \mathrm{ppm} \mathrm{B})$ demonstrate that $\mathrm{B}$ interacts strongly with the aluminosilicate network forming Si-O-B and maybe Al-O-B units and that the proportion of interconnected borate units (B-O-B) is rather small (Schmidt et al., 2004). Considering the high B content in the 'High B' melt (i.e., 7950-8975 ppm, 1073 K) in the experiments of Maner and London (2018), the relevant complex boron structures with different $\mathrm{B} / \mathrm{Si}$ ordering similar to type-I or type-II in white micas may have formed. As shown in Table $\mathrm{A} 1$, there is an average difference of $1.9 \pm 0.7 \%$ in $1000 \ln \beta$ between $\mathrm{BO}_{4}$ clusters and type-II white micas (i.e., $13.5 \%$ for type-II white micas vs. $15.4 \%$ for $\mathrm{BO}_{4}$ cluster in mica fragments) at $1073 \mathrm{~K}$, which is equivalent to the observed difference in $\Delta^{11} \mathrm{~B}_{\text {melt-fluid }}$ between the 'High B' and 'Low B' melts in the experiment of Maner and London (2018). 
Our calculations agree well with the experiments of London (1997) that were run with 1-4 $\mathrm{wt} \% \mathrm{~B}_{2} \mathrm{O}_{3}$, therefore they should be appropriate for natural silicate magmas where boron is generally a trace or minor component. In addition, a small proportion of $\mathrm{B}(\mathrm{OH}) 4^{-}$in the fluid (e.g., $10 \%$ ) only produces a minor shift of $<+0.5 \%$ in $\Delta^{11} \mathrm{~B}_{\text {melt-fluid }}$ at temperatures above 1000 $\mathrm{K}$. The analytical uncertainty of \pm 0.04 in the determined $\mathrm{R}\left(\mathrm{BO}_{4}\right)$ of silicate melt (Tonarini et al., 2003) would also only cause a shift of $< \pm 0.2 \%$ in $\Delta^{11} \mathrm{~B}_{\text {melt-mica. }}$

\subsection{Application to natural systems}

\subsubsection{Boron isotope geothermometers for magmatic-hydrothermal ore deposits}

Reconstructing the thermal evolution of hydrothermal ore deposits using the fluid inclusion record is limited by the difficulty of reliably estimating the trapping conditions (independent estimates of temperature or pressure are generally required). However, the coexistence of mica and tourmaline in many granite-hosted hydrothermal ore deposits and the fractionation of boron isotopes between these minerals, however, provides a reliable means of estimating temperature in such magmatic-hydrothermal systems.

The granite-hosted Panasqueira W-Sn deposit in Central Portugal, is the largest tungsten deposit in Europe, and likely formed from magmatic hydrothermal fluids. It is characterized by a paragenetic sequence comprising a pre-ore crack seal stage, a pre- to synore white mica selvage formation stage, an oxide-silicate ore stage, the main sulfide ore stage, a pyrrhotite alteration stage and a post-ore late carbonate stage (Codeço et al., 2019). White mica is one of the most abundant phases, occurring in all stages of the vein system, whereas tourmaline is a major mineral phase in the wall-rock alteration zones and occurs in some vein selvages (Codeço et al., 2019). A variety of geothermometers have been employed to estimate the temperature of formation of the Panasqueira deposit and have produced a wide range of values. For example, fluid inclusion homogenization temperatures have been used to infer the minimum mineralization temperature of 230 to $~ 360{ }^{\circ} \mathrm{C}$ (Kelly and Rye, 1979; Bussink, 1984; 
Jaques and Pascal, 2017; Lecumberri-Sanchez et al., 2017). In contrast, arsenopyrite geothermometry yielded temperatures ranging from 380 to $640{ }^{\circ} \mathrm{C}$ (Kelly and Rye, 1979; Sharp et al., 1985; Mignardi et al., 1995; Jaques and Pascal, 2017), and Ti-in-quartz thermometry, temperatures of $\sim 400$ to $550{ }^{\circ} \mathrm{C}$ (assuming a pressure of $100 \mathrm{MPa}$; Codeço et al., 2017).

Codeço et al. (2019) re-evaluated the temperature of mineralization and alteration at Panasqueira using the experimentally determined muscovite-tourmaline boron isotope fractionation of Meyer et al. (2008) and Wunder et al. (2005) (i.e., $\Delta^{11} B_{\text {mica-tourmaline }}=-6.49 \times$ 1000/T $(K)+0.36)$. This involved the following samples: PN46B, PN22B and PN33A from a quartz-mica-wolframite vein with a mica-rich selvage, PN30C from a quartz-chalcopyritewolframite vein with a mica-poor selvage, PN26AB from a cassiterite-quartz vein and PN372 from a late fault. The temperatures obtained for these samples were in the range 350 to 500 ${ }^{\circ} \mathrm{C}$ for the vein selvages (i.e., PN33A, PN46B, PN30C) and 220 to $320{ }^{\circ} \mathrm{C}$ for the late fault zone (PN37-2).

As discussed in Sections 4.1 and 4.2, the temperature dependence of $1000 \ln \alpha_{\text {mica-tur }}$ derived from the experimental $1000 \ln \alpha_{\text {mica-fluid }}$ values (Wunder et al., 2005; Meyer et al., 2008) is less than that from theoretical predictions (Kowalski et al., 2013 and this work) and experimental measurement of natural samples. We re-estimated the temperature ranges for the above samples obtained using the equation for boron isotope fractionation between white mica and tourmaline derived in this study (Table 2). From these equations, the mean temperatures for the quartzchalcopyrite-wolframite vein (PN30C) is $653 \pm 76{ }^{\circ} \mathrm{C}$, for the quartz-mica wolframite veins $(\mathrm{PN} 33 \mathrm{~A}, \mathrm{PN} 46 \mathrm{~B})$ are $581 \pm 72{ }^{\circ} \mathrm{C}(\mathrm{PN} 37-2)$ and $621 \pm 74{ }^{\circ} \mathrm{C}(\mathrm{PN} 46 \mathrm{~B})$, and for the cassiteritequartz vein $(\mathrm{PN} 26 \mathrm{AB})$ and late fault zone are $480 \pm 65^{\circ} \mathrm{C}$ and $468 \pm 64{ }^{\circ} \mathrm{C}$, respectively (Fig. 9). A high temperature of $673 \pm 77{ }^{\circ} \mathrm{C}$ for sample PN22B from the quartz-mica-wolframite vein is not reliable because it is uncertain that tourmaline and mica are cogenetic in this sample. 
The analytical uncertainties in the SIMS boron isotope ratios for tourmaline and mica in these samples are \pm 0.6 and $\pm 1.5 \%$ o $(1 \sigma)$, respectively, which corresponds to an uncertainty in the temperature of $\pm 50{ }^{\circ} \mathrm{C}$ to $\pm 94{ }^{\circ} \mathrm{C}$ after error propagation for the low- and high- temperature range, respectively. These errors are similar to those for the white mica-tourmaline fractionation equations relating to differences in the chemical composition and structures of the minerals $\left( \pm 64{ }^{\circ} \mathrm{C}\right.$ and $\pm 77^{\circ} \mathrm{C}$ ). In addition to the analytical uncertainties in boron isotope analysis, it is noteworthy that Codeço et al. (2019) reported variations in $\delta^{11} \mathrm{~B}$, of up to $\pm 5 \%$ for multiple analyses of the same tourmaline and mica crystals. The heterogeneity in $\delta^{11} \mathrm{~B}$ within individual crystals likely reflects compositional zonation which, in turn, could reflect fluctuations in the temperature, $\mathrm{pH}$, and composition of the fluid. Given the uncertainties referred to above, the temperatures of crystallization of the Panasqueira samples are most reliably estimated by the median values.

Codeço et al. (2019) calculated lower temperatures than estimated by us because they used the temperature dependence of muscovite-tourmaline fractionation developed from the experimental data of tourmaline-fluid by Meyer et al. (2008) and muscovite-fluid by Wunder et al. (2005). Whereas the tourmaline experiments were conducted under acidic conditions for which the fluid contained essentially $100 \% \mathrm{BO}_{3}$ (Meyer et al., 2008), and the fluid used in the muscovite experiments contained varying proportions of both $\mathrm{BO}_{3}$ and $\mathrm{BO}_{4}$ (Wunder et al., 2005). This difference boron speciation of the aqueous fluids has a strong influence on boron isotope fractionation between minerals and fluid, and, in turn, on the tourmaline-mica fractionation (as illustrated in Fig. 5). In contrast, the theoretical approach employed in our study does not make any assumptions concerning the fluid speciation (although both species must be present if muscovite and tourmaline are to precipitate contemporaneously from the same fluid). Instead, the calculated fractionation factor depends solely on the difference in boron coordination between the two minerals. Moreover, the theoretical $\Delta^{11} \mathrm{~B}_{\text {mica-tur }}$ values are 
close to those measured in natural samples (e.g., Klemme et al., 2011), but greater than those estimated from the experimental $\Delta^{11} \mathrm{~B}_{\text {mica-fluid }}$ and $\Delta^{11} \mathrm{~B}_{\text {tur-fluid }}$ data. Finally, we caution that direct evidence of the attainment of equilibrium between mineral pairs of interest needs to be verified before applying the boron isotope geothermometer.

\subsubsection{Reconstruction of the original boron isotope signatures of fluids and melts}

The calculations presented above make it possible to quantitatively assess equilibrium boron isotope fractionation among minerals, fluid and melt. If the $\delta^{11} \mathrm{~B}_{\text {mica }}, \delta^{11} \mathrm{~B}_{\text {tur }}$ and $\mathrm{R}\left(\mathrm{BO}_{4}\right)$ melt values are known, the temperature of the crystallization of the minerals as well as $\delta^{11} B_{\text {melt, }}$ $\delta^{11} \mathrm{~B}_{\text {fluid }}$ can be determined, as shown schematically in Fig. 10.

On the basis of $\delta^{11} \mathrm{~B}$ in muscovite and tourmaline in the granite-hosted Panasqueira W-Sn deposit, the $\delta^{11} \mathrm{~B}$ of the fluid is estimated to have varied from -5.0 to $-9.0 \%$, as illustrated in Fig. 9. Assuming the $\mathrm{R}\left(\mathrm{BO}_{4}\right)$ in the melt to be $0,0.3$ and 0.5 , the $\delta^{11} \mathrm{~B}$ in melts were estimated to be -6.8 to $-10.8 \%,-9.3$ to $-13.3 \%$ and -10.9 to $-14.9 \%$, at a temperature of $800 \mathrm{~K}$, which are consistent with the $\delta^{11} \mathrm{~B}$ distribution in S-type silicate rocks $(-11 \pm 4 \%$ ) (Trumbull and Slack, 2018). Thus, the boron isotope data imply that the tungsten deposits at Panasquiera were produced by fluids exsolved from the adjacent S-type Panasqueira granite.

\subsubsection{Additional factors influencing boron isotope fractionation}

In addition to chemical composition and the $\mathrm{B} / \mathrm{Si}$ ordering in mineral lattices, the effect of pressure on boron isotope fractionation among liquid, melt and minerals needs to be considered. The effect of pressure on the fractionation of isotopes between two minerals depends mainly on the coordination environment (e.g., channels, layers of polyhedra, facecentered and body-centered), and varies from negligible (e.g., sulfur isotope fractionation among sulfide minerals, Hamann et al., 1984) to significant (e.g., magnesium isotope fractionation among mantle minerals, Huang et al., 2013). 
In mineral-fluid systems at high pressure, both the structure and density of the fluids change far more than the minerals do, and in principle, this could significantly affect isotopic fractionation. In the case of hydrogen, the effect is considerable (Polyakov and Kharlashina, 1994; Horita et al., 1999), whereas for oxygen, it is negligible $(\leq 0.2 \%$ ) for many mineral (e.g., quartz, calcite, albite and wollastonite) in aqueous systems at pressures as high as $2.2 \mathrm{GPa}$ (Horita et al., 2002).

On the basis of spectral measurements and force field simulations, Sanchez-Valle et al. (2005) concluded that the effect of pressure on boron isotope fractionation in liquid solutions is negligible up to $10 \mathrm{GPa}$ and $723 \mathrm{~K}$ relative to temperature or speciation ( $\mathrm{pH}$ ) effects. For mineral-fluid systems, Kowalski et al. (2013) showed that, although there is a pressure effect on the $\beta$ factors for boron isotopes in aqueous solutions, after correcting for the effects of both high $\mathrm{T}$ and $\mathrm{P}$, the resulting isotope fractionation factor between boromuscovite and aqueous fluid is very similar to that at ambient pressure. Meyer et al. (2008) showed that there is also no measurable pressure dependence on the isotope fractionation of boron between tourmaline and fluid at $500{ }^{\circ} \mathrm{C}$ and up to $500 \mathrm{MPa}$. As the effect of pressure on boron isotope fractionation is still unclear, we recommend that the results of this study not be applied to systems for which the pressure is higher than $1 \mathrm{GPa}$, especially if the system contains an aqueous fluid. For pressures $\leq 1 \mathrm{GPa}$, the boron isotope fractionation equations developed in this study can be applied to most systems containing the mineral pair of tourmaline and white mica in equilibrium, and may help in further understanding systems such as those forming magmatic hydrothermal deposits particularly for issues relating to the sources of the fluids and magmas (e.g., Trumbull et al., 2013). It is important to note, however, that in natural systems, the boron isotope evolution of silicate melts is complicated by the fact that it is influenced by crystallization, fluid exsolution and the introduction of boron from external reservoirs. 
In addition to equilibrium boron isotope fractionation, the kinetic effect on the evolution of $\delta^{11} \mathrm{~B}$ in residual melts because of the boron removal by the crystallization of minerals and fluid exsolution must be considered, as there is a significant boron loss during phase separation. Using the same conditions as Trumbull et al. (2013) (i.e., a starting condition with $\delta^{11} \mathrm{~B}$ of $-14 \%$ and $\mathrm{T}$ of $\left.\sim 500{ }^{\circ} \mathrm{C}\right)$, the impact of the $\mathrm{R}\left(\mathrm{BO}_{4}\right)$ values of silicate melts and aqueous fluid on boron isotope evolution in magmas during Rayleigh fractionation has been evaluated (Fig. 11). The maximum boron partitioning coefficient, $D_{\text {fluid-melt }}$, observed in experiments between melts and fluids is 4.6 (Schatz et al., 2004). Assuming a $\mathrm{R}\left(\mathrm{BO}_{4}\right)$ value of 0.5 in the melt, the $6 \%$ of shift in $\delta^{11}$ Bmelt from the outer to the inner zones of the Borborema pegmatite (Trumbull et al., 2013) may have resulted from about $70 \%$ removal of boron by tourmaline crystallization or by an exsolved acid fluid having a $\mathrm{R}\left(\mathrm{BO}_{4}\right)$ of 0.1 . By contrast, even $90 \%$ removal of boron by an exsolved neutral fluid with a $\mathrm{R}\left(\mathrm{BO}_{4}\right)$ of 0.5 , cannot cause a large decrease in $\delta^{11} \mathrm{~B}_{\text {melt. }}$

\section{Conclusions}

Cluster models of the $\mathrm{BO}_{3}$ and $\mathrm{BO}_{4}$ units in silicate melts for a wide range of chemical compositional variability were developed in this study, and can be used to assess equilibrium boron isotope fractionation in magmatic-hydrothermal systems. After assessing the applicability of the simplified treatment of boron coordination structures in silicate melts, the principal conclusions of the study are: (i) In co-existing boron-bearing minerals, chemical replacement reactions play a relative minor role in boron isotope fractionation $(<2 \%$ at 600 $\mathrm{K}$ ); (ii) $\mathrm{B} / \mathrm{Si}$ disorder in the tetrahedral layer of boron-enriched silicate minerals, such as white mica, result in within crystalline $\delta^{11} \mathrm{~B}$ variations that average $2.9 \%$ at $600 \mathrm{~K}$; (iii) In muscovitefluid systems, the temperature dependency of boron isotope fractionation is greater for acidic fluids than for basic fluids, reinforcing the conclusion that the difference in the coordination of 
boron in trigonal/tetrahedral structures in the two phases dominates boron isotope fractionation; (iv) In silicate magmas, boron coordination controls boron isotopic fractionation between melt and crystallizing minerals. At magmatic temperatures, the proportion of the $\mathrm{BO}_{4}$ unit is highly variable and the $\Delta^{11} \mathrm{~B}$ values between mineral/fluid and melt vary with $\mathrm{R}\left(\mathrm{BO}_{4}\right)$ unit in the melt; (v) Theoretical predictions for boron isotope fractionation among muscovite, tourmaline, silicate melt and aqueous liquid facilitate the application of white mica-tourmaline geothermometry to magmatic-hydrothermal ore-forming systems and the evaluation of fluid/melt sources in these systems.

\section{Declaration of Competing Interest}

The authors declare no conflict of interest.

\section{Acknowledgements}

This research was supported by the National Natural Science Foundations of China (Grants Nos. 41973005, 41673001, 41830428, 41422302) and China National Space Administration (CNSA) (Grant No. D020205). We are grateful to the High Performance Computing Center (HPCC) of Nanjing University for processing the numerical calculations in this paper using its blade cluster system. The authors are grateful to the anonymous reviewers for their constructive and insightful comments that have improved the manuscript significantly. The careful editorial handling by Prof. Michael E. Böttcher is greatly appreciated.

\section{References}

Antonelli, M.A., Schiller, M., Schauble, E.A., Mittal, T., DePaolo, D.J., Chacko, T., Grew, E.S., Tripoli, B., 2019. Kinetic and equilibrium ca isotope effects in high-T rocks and minerals. Earth Planet. Sci. Lett. 517, 71-82. 
Balan, E., Noireaux, J., Mavromatis, V., Saldi, G.D., Montouillout, V., Blanchard, M., Pietrucci, F., Gervais, C., Rustad, J.R., Schott, J., Gaillardet, J., 2018. Theoretical isotopic fractionation between structural boron in carbonates and aqueous boric acid and borate ion. Geochim. Cosmochim. Acta 222, 117-129.

Balan, E., Cr'eon, L., Sanloup, C., Al’eon, J., Blanchard, M., Paulatto, L., Bureau, H., 2019. Firstprinciples modeling of chlorine isotope fractionation between chloride-bearing molecules and minerals. Chem. Geol. 525, 424-434.

Bebout, G.E., Nakamura, E., 2003. Record in metamorphic tourmalines of subduction-zone devolatilization and boron cycling. Geology 31, 407-410.

Bebout, G.E., Bebout, A.E., Graham, C.M., 2007. Cycling of B, Li, and LILE (K, Cs, Rb, Ba, Sr) into subduction zones: SIMS evidence from micas in high-P/T metasedimentary rocks. Chem. Geol. 239, 284-304.

Belley, P.M., Grice, J.D., Fayek, M., Kowalski, P.M., Grew, E.S., 2014. A new occurrence of the borosilicate serendibite in tourmaline-bearing calc-silicate rocks, portage-dufort marble, Grenville province, Québec: evolution of boron isotope and tourmaline compositions in a metamorphic context. Can. Mineral. 52, 595-616.

Benton, L.D., Ryan, J.G., Tera, F., 2001. Boron isotope systematics of slab fluids as inferred from a serpentine seamount, Mariana forearc. Earth Planet. Sci. Lett. 187, 273-282.

Bigeleisen, J., Mayer, M.G., 1947. Calculation of equilibrium constants for isotopic exchange reactions. J. Chem. Phys. 15, 261-267.

Blanchard, M., Poitrasson, F., M’eheut, M., Lazzeri, M., Mauri, F., Balan, E., 2009. Iron isotope fractionation between pyrite $\left(\mathrm{FeS}_{2}\right)$, hematite $\left(\mathrm{Fe}_{2} \mathrm{O}_{3}\right)$ and siderite $\left(\mathrm{FeCO}_{3}\right)$ : a first-principles density functional theory study. Geochim. Cosmochim. Acta 73, 6565-6578.

Blanchard, M., Balan, E., Schauble, E.A., 2017. Equilibrium Fractionation of Nontraditional Isotopes: a molecular modeling perspective. Rev. Mineral. Geochem. 82, 27-63. 
Bussink, R.W., 1984. Geochemistry of the Panasqueira Tungsten-Tin Deposit, Portugal. Instituut voor Aardwetenschappen der Rijksuniversiteit te Utrecht.

Cao, M.-Y., Jiang, S.-Y., Su, H.-M., Zhao, K.-D., Chen, W., 2018. Chemical and boron isotopic composition of tourmaline and muscovite in granite and pegmatite from Cizhu pluton, Jiangxi Province, South China: insight to magmatic-hydrothermal evolution. Goldschmidt Abstr. 2018, 332.

Chakraborty, S., Dingwell, D.B., Chaussidon, M., 1993. Chemical diffusivity of boron in melts of haplogranitic composition. Geochim. Cosmochim. Acta 57 (8), 1741-1751.

Christ, C., 1965. Substitution of boron in silicate crystals. Nor. Geol. Tidsskr. 45, 423-428.

Clark, S.J., Segall, M.D., Pickard, C.J., Hasnip, P.J., Probert, M.I., Refson, K., Payne, M.C., 2005. First principles methods using CASTEP. Z. Krist.-Cryst. Mater. 220, 567-570.

Codeço, M.S., Weis, P., Trumbull, R.B., Pinto, F., Lecumberri-Sanchez, P., Wilke, F.D., 2017. Chemical and boron isotopic composition of hydrothermal tourmaline from the Panasqueira W-Sn-Cu deposit, Portugal. Chem. Geol. 468, 1-16.

Codeço, M.S., Wiedenbeck, M., Weis, P., Trumbull, R.B., Glodny, J., Romer, R.L., 2019. Boron isotope muscovite-tourmaline geothermometry indicates fluid cooling during magmatichydrothermal W-Sn ore formation. Econ. Geol. 114, 153-163.

De Hoog, J.C.M., Savov, I.P., 2018. Boron isotopes as a tracer of subduction zone processes. In: Marschall, H., Foster, G. (Eds.), Boron Isotopes: The Fifth Element. Springer International Publishing, Cham, pp. 217-247.

De Koker, N., Stixrude, L., Karki, B.B., 2008. Thermodynamics, structure, dynamics, and melting of $\mathrm{Mg}_{2} \mathrm{SiO}_{4}$ liquid at high pressure. Geochim. Cosmochim. Acta 72, 1427-1441.

Deegan, F.M., Troll, V.R., Whitehouse, M.J., Jolis, E.M., Freda, C., 2016. Boron isotope fractionation in magma via crustal carbonate dissolution. Sci. Rep. 6, 30774. 
Deer, W.A., Howie, R.A., Zussman, J., 2013. An Introduction to the Rock-Forming Minerals (3rd ed.). Mineralogical Society, London, p. 498.

Dell, W.J., Bray, P.J., Xiao, S.Z., 1983. ${ }^{11}$ B NMR studies and structural modeling of $\mathrm{Na}_{2} \mathrm{OB}_{2} \mathrm{O}_{3}$ $\mathrm{SiO}_{2}$ glasses of high soda content. J. Non-Cryst. Solids 58, 1-16.

Dingwell, D.B., Pichavant, M., Holtz, F., 1996. Experimental studies of boron in silicate melts. Rev. Mineral. Geochem. 33, 330-385.

Domanik, K.J., Hervig, R.L., Peacock, S.M., 1993. Beryllium and boron in subduction zone minerals: an ion microprobe study. Geochim. Cosmochim. Acta 57, 4997-5010.

Dominguez, G., Wilkins, G., Thiemens, M., 2011. The Soret effect and isotopic fractionation in high-temperature silicate melts. Nature 473, 70-73.

Downs, R.T., Hall-Wallace, M., 2003. The American Mineralogist crystal structure database. Am. Mineral. 88, 247-250.

Du, L.S., Allwardt, J., Schmidt, B., Stebbins, J., 2004. Pressure-induced structural changes in a borosilicate glass-forming liquid: boron coordination, non-bridging oxygens, and network ordering. J. Non-Cryst. Solids 337, 196-200.

Ducher, M., Blanchard, M., Balan, E., 2016. Equilibrium zinc isotope fractionation in Zn-bearing minerals from first-principles calculations. Chem. Geol. 443, 87-96.

Ducher, M., Blanchard, M., Balan, E., 2018. Equilibrium isotopic fractionation between aqueous Zn and minerals from first-principles calculations. Chem. Geol. 483, 342-350.

Edwards, T., Endo, T., Walton, J.H., Sen, S., 2014. Observation of the transition state for pressure induced $\mathrm{BO}_{3} \rightarrow \mathrm{BO}_{4}$ conversion in glass. Science 345, 1027-1029.

Frisch, M.J., Trucks, G.W., Schlegel, H.B., Scuseria, G.E., Robb, M.A., Cheeseman, J.R., Scalmani, G., Barone, V., Petersson, G.A., Nakatsuji, H., Li, X., Caricato, M., Marenich, A.V., Bloino, J., Janesko, B.G., Gomperts, R., Mennucci, B., Hratchian, H. P., Ortiz, J.V., Izmaylov, A.F., Sonnenberg, J.L., Williams Ding, F., Lipparini, F., Egidi, F., Goings, J., Peng, B., 
Petrone, A., Henderson, T., Ranasinghe, D., Zakrzewski, V.G., Gao, J., Rega, N., Zheng, G., Liang, W., Hada, M., Ehara, M., Toyota, K., Fukuda, R., Hasegawa, J., Ishida, M., Nakajima, T., Honda, Y., Kitao, O., Nakai, H., Vreven, T., Throssell, K., Montgomery Jr., J.A., Peralta, J.E., Ogliaro, F., Bearpark, M.J., Heyd, J.J., Brothers, E.N., Kudin, K.N., Staroverov, V.N., Keith, T.A., Kobayashi, R., Normand, J., Raghavachari, K., Rendell, A.P., Burant, J.C., Iyengar, S. S., Tomasi, J., Cossi, M., Millam, J.M., Klene, M., Adamo, C., Cammi, R., Ochterski, J. W., Martin, R.L., Morokuma, K., Farkas, O., Foresman, J.B., Fox, D.J., 2016. Gaussian 16, Wallingford, CT.

Geisinger, K.L., Oestrike, R., Navrotsky, A., Turner, G.L., Kirkpatrick, R.J., 1988. Thermochemistry and structure of glasses along the join $\mathrm{NaAlSi}_{3} \mathrm{O}_{8}-\mathrm{NaBSi}_{3} \mathrm{O}_{8}$. Geochim. Cosmochim. Acta 52, 2405-2414.

Goel, G., Zhang, L., Lacks, D.J., Van Orman, J.A., 2012. Isotope fractionation by diffusion in silicate melts: Insights from molecular dynamics simulations. Geochim. Cosmochim. Acta 93, $205-213$.

Hamann, S.D., Shaw, R.M., Lusk, J., Batts, B.D., 1984. Isotopic volume differences: the possible influence of pressure on the distribution of sulfur isotopes between sulphide minerals. Aust. J. Chem. 37, 1979-1989.

Hansen, C.T., Meixner, A., Kasemann, S.A., Bach, W., 2017. New insight on Li and B isotope fractionation during serpentinization derived from batch reaction investigations. Geochim. Cosmochim. Acta 217, 51-79.

Harvey, J., Garrido, C.J., Savov, I., Agostini, S., Padron-Navarta, J.A., Marchesi, C., SanchezVizcaíno, V.L., Gomez-Pugnaire, M.T., 2014. ${ }^{11}$ B-rich fluids in subduction zones: the role of antigorite dehydration in subducting slabs and boron isotope heterogeneity in the mantle. Chem. Geol. 376, 20-30. 
Hawthorne, F.C., Burns, P.C., Grice, J.D., 1996. The crystal chemistry of boron. Rev. Mineral. Geochem. 33, 41-115.

Hervig, R.L., Moore, G.M., Williams, L.B., Peacock, S.M., Holloway, J.R., Roggensack, K., 2002. Isotopic and elemental partitioning of boron between hydrous fluid and silicate melt. Am. Mineral. 87, 769-774.

Hill, P.S., Schauble, E.A., 2008. Modeling the effects of bond environment on equilibrium iron isotope fractionation in ferric aquo-chloro complexes. Geochim. Cosmochim. Acta 72, 19391958.

Horita, J., Driesner, T., Cole, D.R., 1999. Pressure effect on hydrogen isotope fractionation between brucite and water at elevated temperatures. Science 286, 1545.

Horita, J., Cole, D.R., Polyakov, V.B., Driesner, T., 2002. Experimental and theoretical study of pressure effects on hydrogen isotope fractionation in the system brucite-water at elevated temperatures. Geochim. Cosmochim. Acta 66, 3769-3788.

Huang, F., Chen, L., Wu, Z., Wang, W., 2013. First-principles calculations of equilibrium Mg isotope fractionations between garnet, clinopyroxene, orthopyroxene, and olivine: Implications for Mg isotope thermometry. Earth Planet. Sci. Lett. 367, 61-70.

Huang, F., Wu, Z., Huang, S., Wu, F., 2014. First-principles calculations of equilibrium silicon isotope fractionation among mantle minerals. Geochim. Cosmochim. Acta 140, 509-520.

Huang, F., Zhou, C., Wang, W., Kang, J., Wu, Z., 2019. First-principles calculations of equilibrium $\mathrm{Ca}$ isotope fractionation: Implications for oldhamite formation and evolution of lunar magma ocean. Earth Planet. Sci. Lett. 510, 153-160.

Ishikawa, T., Nakamura, E., 1994. Origin of the slab component in arc lavas from across-arc variation of $\mathrm{B}$ and $\mathrm{Pb}$ isotopes. Nature 370, 205-208. 
Jaques, L., Pascal, C., 2017. Full paleostress tensor reconstruction using quartz veins of Panasqueira Mine, central Portugal; part I: Paleopressure determination. J. Struct. Geol. 102, $58-74$.

Jiang, S.Y., Slack, J.F., Palmer, M.R., 2000. Sm-Nd dating of the giant Sullivan Pb-Zn-Ag deposit, British Columbia. Geology 28, 751-754.

Kakihana, H., Kotaka, M., Satoh, S., Nomura, M., Okamoto, M., 1977. Fundamental studies on the ion-exchange separation of boron isotopes. B. Chem. Soc. Jpn. 50, 158-163.

Karki, B.B., 2010. First-principles molecular dynamics simulations of silicate melts: structural and dynamical properties. Rev. Mineral. Geochem. 71 (1), 355-389.

Karki, B.B., Bhattarai, D., Stixrude, L., 2006a. First principles calculations of the structural, dynamical and electronic properties of liquid MgO. Phys. Rev. B 73, 174208.

Karki, B.B., Bhattarai, D., Stixrude, L., 2006b. A first-principles computational framework for liquid mineral systems. Com. Mat. Cont. 3, 107-118.

Karki, B.B., Bhattarai, D., Stixrude, L., 2007. First-principles simulations of liquid silica: structural and dynamical behavior at high pressure. Phys. Rev. B 76, 104205.

Karki, B.B., Bhattarai, D., Mookherjee, M., Stixrude, L., 2009. Visualization-based analysis of structural and dynamical properties of simulated hydrous silicate melt. Phys. Chem. Miner. 37, $103-117$.

Kelly, W.C., Rye, R.O., 1979. Geologic, fluid inclusion, and stable isotope studies of the tintungsten deposits of Panasqueira, Portugal. Econ. Geol. 74, 1721-1822.

Klemme, S., Marschall, H.R., Jacob, D.E., Prowatke, S., Ludwig, T., 2011. Trace-element partitioning and boron isotope fractionation between white mica and tourmaline. Can. Mineral. 49, 165-176.

Konrad-Schmolke, M., Halama, R., 2014. Combined thermodynamic-geochemical modeling in metamorphic geology: Boron as tracer of fluid-rock interaction. Lithos 208-209, 393-414. 
Kowalski, P.M., Jahn, S., 2011. Prediction of equilibrium Li isotope fractionation between minerals and aqueous solutions at high $\mathrm{P}$ and $\mathrm{T}$ : an efficient ab initio approach. Geochim. Cosmochim. Acta 75, 6112-6123.

Kowalski, P.M., Wunder, B., 2018. Boron isotope fractionation among vapor-liquids-solidsmelts: experiments and atomistic modeling. In: Marschall, H., Foster, G. (Eds.), Boron Isotopes: The Fifth Element. Springer International Publishing, Cham, pp. 33-69.

Kowalski, P.M., Wunder, B., Jahn, S., 2013. Ab initio prediction of equilibrium boron isotope fractionation between minerals and aqueous fluids at high $\mathrm{P}$ and T. Geochim. Cosmochim. Acta 101, 285-301.

Kutzschbach, M., Wunder, B., Trumbull, R., Meixner, A., Rhede, D., Heinrich, W., Franz, G., 2016. The Effect of Tetrahedral B in the B Isotope Fractionation between Tourmaline and Fluid. GeoBerlin, Berlin.

Lecumberri-Sanchez, P., Vieira, R., Heinrich, C.A., Pinto, F., Wälle, M., 2017. Fluid-rock interaction is decisive for the formation of tungsten deposits. Geology 45, 579-582.

Leeman, W., Sisson, V., 1996. Geochemistry of boron and its implications for crustal and mantle processes. Rev. Mineral. Geochem. 33, 645-707.

Li, Y., Wang, W., Huang, S., Wang, K., Wu, Z., 2019. First-principles investigation of the concentration effect on equilibrium fractionation of $\mathrm{K}$ isotopes in feldspars. Geochim. Cosmochim. Acta 245, 374-384.

Li, Y.C., Chen, H.W., Wei, H.Z., Jiang, S.Y., Palmer, M.R., Van De Ven, T.G.M., Hohl, S., Lu, J.J., Ma, J., 2020. Exploration of driving mechanisms of equilibrium boron isotope fractionation in tourmaline group minerals and fluid: a density functional theory study. Chem. Geol. 536, 119466. 
Liang, J.J., Hawthorne, F.C., Novak, M., Cerny, P., Ottolini, L., 1995. Crystal-structure refinement of boromuscovite polytypes using a coupled rietveld static-structure energyminimization method. Can. Mineral. 33, 859-865.

Liu, Y., Tossell, J.A., 2005. Ab initio molecular orbital calculations for boron isotope fractionations on boric acids and borates. Geochim. Cosmochim. Acta 69, 3995-4006.

Liu, X., Qi, Y., Zheng, D., Zhou, C., He, L., Huang, F., 2018. Diffusion coefficients of Mg isotopes in $\mathrm{MgSiO}_{3}$ and $\mathrm{Mg}_{2} \mathrm{SiO}_{4}$ melts calculated by first-principles molecular dynamics simulations. Geochim. Cosmochim. Acta 223, 364-376.

London, D., 1997. Estimating abundances of volatile and other mobile components in evolved silicic melts through mineral-melt equilibria. J. Petrol. 38, 1691-1706.

London, D., Hervig, R.L., Morgan, G.B., 1988. Melt-vapor solubilities and elemental partitioning in peraluminous granite-pegmatite systems: experimental results with Macusani glass at 200 MPa. Contrib. Mineral. Petrol. 99, 360-373.

London, D., Morgan, G.B., Wolf, M.B., 1996. Boron in silicate rocks and their contact aureoles. Rev. Mineral. Geochem. 33, 299-330.

Manara, D., Grandjean, A., Neuville, D., 2009. Advances in understanding the structure of borosilicate glasses: a Raman spectroscopy study. Am. Mineral. 94, 777-784.

Maner, J.L., London, D., 2018. Fractionation of the isotopes of boron between granitic melt and aqueous solution at $700{ }^{\circ} \mathrm{C}$ and $800{ }^{\circ} \mathrm{C}(200 \mathrm{MPa})$. Chem. Geol. 489, 16-27.

Martin, B., Spera, F.J., Ghiorso, M., Nevins, D., 2009. Structure, thermodynamic and transport properties of molten $\mathrm{Mg} 2 \mathrm{SiO} 4$ : molecular dynamics simulations and model EOS. Am. Mineral. 94, 693-703.

Mavromatis, V., van Zuilen, K., Blanchard, M., van Zuilen, M., Dietzel, M., Schott, J., 2020. Experimental and theoretical modelling of kinetic and equilibrium Ba isotope fractionation during calcite and aragonite precipitation. Geochim. Cosmochim. Acta 269, 566-580. 
M’eheut, M., Schauble, E.A., 2014. Silicon isotope fractionation in silicate minerals: Insights from first-principles models of phyllosilicates, albite and pyrope. Geochim. Cosmochim. Acta $134,137-154$.

M’eheut, M., Lazzeri, M., Balan, E., Mauri, F., 2007. Equilibrium isotopic fractionation in the kaolinite, quartz, water system: Prediction from first-principles density-functional theory. Geochim. Cosmochim. Acta 71, 3170-3181.

M’eheut, M., Lazzeri, M., Balan, E., Mauri, F., 2009. Structural control over equilibrium silicon and oxygen isotopic fractionation: a first-principles density-functional theory study. Chem. Geol. 258 (1-2), 0-37.

M’eheut, M., Lazzeri, M., Balan, E., Mauri, F., 2010. First-principles calculation of H/D isotopic fractionation between hydrous minerals and water. Geochim. Cosmochim. Acta 74, 38743882.

Menold, C.A., Grove, M., Sievers, N.E., Manning, C.E., Yin, A., Young, E.D., Ziegler, K., 2016. Argon, oxygen, and boron isotopic evidence documenting ${ }^{40} \mathrm{Ar}^{\mathrm{E}}$ accumulation in phengite during water-rich high-pressure subduction metasomatism of continental crust. Earth Planet. Sci. Lett. 446, 56-67.

Merrick, J.P., Moran, D., Radom, L., 2007. An evaluation of harmonic vibrational frequency scale factors. J. Phys. Chem. A 111, 11683-11700.

Meyer, C., Wunder, B., Meixner, A., Romer, R.L., Heinrich, W., 2008. Boron-isotope fractionation between tourmaline and fluid: an experimental re-investigation. Contrib. Mineral. Petrol. 156, 259-267.

Michel, F., Cormier, L., Lombard, P., Beuneu, B., Galoisy, L., Calas, G., 2013. Mechanisms of boron coordination change between borosilicate glasses and melts. J. Non-Cryst. Solids 379, $169-176$. 
Mignardi, S., Ferrini, V., Masi, U., Conde, L.N., Sousa, M.B., 1995. Significance of the arsenopyrite composition from hydrothermal wolframite deposits of Panasqueira and Vale das Gatas (Portugal). XIII Reuniao de Geologia do Oeste Peninsular 187-190.

Mysen, B., 2010. Structure of $\mathrm{H}_{2} \mathrm{O}$-saturated peralkaline aluminosilicate melt and coexisting aluminosilicate-saturated aqueous fluid determined in-situ to $80 \circ^{\circ} \mathrm{C}$ and $\sim 800 \mathrm{MPa}$. Geochim. Cosmochim. Acta 74, 4123-4139.

Navrotsky, A., 1996. Thermochemistry of borosilicate melts and glasses; from Pyrex to pegmatites. RRev. Mineral. Geochem. 33, 165-180.

Oi, T., Nomura, M., Musashi, M., Ossaka, T., Okamoto, M., Kakihana, H., 1989. Boron isotopic compositions of some boron minerals. Geochim. Cosmochim. Acta 53, 3189-3195.

Palmer, M.R., 2017. Boron Cycling in Subduction zones. Elements 13, 237-242.

Palmer, M.R., Helvaci, C., 1997. The boron isotope geochemistry of the Neogene borate deposits of western Turkey. Geochim. Cosmochim. Acta 61, 3161-3169.

Palmer, M.R., Slack, J.F., 1989. Boron isotopic composition of tourmaline from massive sulfide deposits and tourmalinites. Contrib. Mineral. Petrol. 103, 434-451.

Palmer, M.R., Swihart, G.H., 1996. Boron isotope geochemistry: an overview. Rev. Mineral. Geochem. 33, 709-744.

Peacock, S.M., Hervig, R.L., 1999. Boron isotopic composition of subduction-zone metamorphic rocks. Chem. Geol. 160, 281-290.

Pichavant, M., Kontak, D.J., Briqueu, L., Herrera, J.V., Clark, A.H., 1988. The Miocene-Pliocene Macusani volcanics, SE Peru. Contrib. Mineral. Petrol. 100, 325-338.

Pinilla, C., Blanchard, M., Balan, E., Ferlat, G., Vuilleumier, R., Mauri, F., 2014. Equilibrium fractionation of $\mathrm{H}$ and $\mathrm{O}$ isotopes in water from path integral molecular dynamics. Geochim. Cosmochim. Acta 135, 203-216. 
Pohlmann, M., Benoit, M., Kob, W., 2004. First-principles molecular dynamics simulations of a hydrous silica melt: structural properties and hydrogen diffusion mechanism. Phys. Rev. B 70, 184209.

Polyakov, V.B., Kharlashina, N.N., 1994. Effect of pressure on equilibrium isotopic fractionation. Geochim. Cosmochim. Acta 58, 4739-4750.

Richter, F.M., Watson, E.B., Mendybaev, R.A., Teng, F.Z., Janney, P.E., 2008. Magnesium isotope fractionation in silicate melts by chemical and thermal diffusion. Geochim. Cosmochim. Acta 72 (1), 206-220.

Rustad, J.R., Bylaska, E.J., 2007. Ab initio calculation of isotopic fractionation in $\mathrm{B}(\mathrm{OH})_{3}(\mathrm{aq})$ and $\mathrm{B}(\mathrm{OH}){ }_{4}^{-}$(aq). J. Am. Chem. Soc. 129, 2222-2223.

Rustad, J.R., Yuen, D.A., Spera, F.J., 1990. Molecular dynamics of liquid $\mathrm{SiO}_{2}$ under high pressure. Phys. Rev. A 42, 2081-2089.

Ryan, J.G., Leeman, W.P., 1996. The boron systematics of intraplate lavas: Implications for crust and mantle evolution. Geochim. Cosmochim. Acta 60, 415-422.

Sanchez-Valle, C., Reynard, B., Daniel, I., Lecuyer, C., Martinez, I., Chervin, J.C., 2005. Boron isotopic fractionation between minerals and fluids: new insights from in situ high pressurehigh temperature vibrational spectroscopic data. Geochim. Cosmochim. Acta 69, 4301-4313.

Scambelluri, M., Tonarini, S., 2012. Boron isotope evidence for shallow fluid transfer across subduction zones by serpentinized mantle. Geology 40, 907-910.

Schatz, O.J., Dolejs, D., Stix, J., Williams-Jones, A.E., Layne, G.D., 2004. Partitioning of boron among melt, brine and vapor in the system haplogranite- $\mathrm{H} 2 \mathrm{O}-\mathrm{NaCl}$ at $800{ }^{\circ} \mathrm{C}$ and $100 \mathrm{MPa}$. Chem. Geol. 210, 135-147.

Schauble, E.A., 2004. Applying stable isotope fractionation theory to new systems. Rev. Mineral. Geochem. 55, 65-111. 
Schauble, E.A., 2011. First-principles estimates of equilibrium magnesium isotope fractionation in silicate, oxide, carbonate and hexaaquamagnesium(2+) crystals. Geochim. Cosmochim. Acta $75,844-869$.

Schauble, E.A., Rossman, G.R., Taylor, H.P., 2001. Theoretical estimates of equilibrium Feisotope fractionations from vibrational spectroscopy. Geochim. Cosmochim. Acta 65, 24872497.

Schauble, E.A., Rossman, G.R., Taylor, H., 2003. Theoretical estimates of equilibrium chlorineisotope fractionations. Geochim. Cosmochim. Acta 67 (17), 3267-3281.

Schauble, E.A., Meheut, M., Hill, P.S., 2009. Combining metal stable isotope fractionation theory with experiments. Elements 5, 369-374.

Schmidt, B.C., Zotov, N., Dupree, R., 2004. Structural implications of water and boron dissolution in albite glass. J. Non-Cryst. Solids 337, 207-219.

Schmidt, C., Thomas, R., Heinrich, W., 2005. Boron speciation in aqueous fluids at 22 to $600{ }^{\circ} \mathrm{C}$ and 0.1 MPa to 2 GPa. Geochim. Cosmochim. Acta 69, 275-281.

Schmitt, A.K., Simon, J.I., 2004. Boron isotopic variations in hydrous rhyolitic melts: a case study from Long Valley, California. Contrib. Mineral. Petrol. 146, 590-605.

Sharp, Z.D., Essene, E.J., Kelly, W.C., 1985. A re-examination of the arsenopyrite geothermometer; pressure considerations and applications to natural assemblages. Can. Mineral. 23, 517-534.

Sievers, N.E., Menold, C.A., Grove, M., Coble, M.A., 2016. White mica trace element and boron isotope evidence for distinctive infiltration events during exhumation of deeply subducted continental crust. Int. Geol. Rev. 59, 18.

Smirnov, S.Z., Thomas, V.G., Demin, S.P., Drebushchak, V.A., 2005. Experimental study of boron solubility and speciation in the $\mathrm{Na}_{2} \mathrm{O}-\mathrm{B}_{2} \mathrm{O}_{3}-\mathrm{SiO}_{2}-\mathrm{H}_{2} \mathrm{O}$ system. Chem. Geol. 223, 16-34. 
Solomatov, V.S., 2007. Magma oceans and primordial mantle differentiation. In: Schubert, G. (Ed.), Treatise in Geophysics, vol. 9. Elsevier, New York, pp. 91-120. Evolution of the Earth. Thomas, R., F"orster, H.J., Heinrich, W., 2003. The behaviour of boron in a peraluminous granitepegmatite system and associated hydrothermal solutions: a melt and fluid-inclusion study. Contrib. Mineral. Petrol. 144, 457-472.

Tonarini, S., Forte, C., Petrini, R., Ferrara, G., 2003. Melt/biotite ${ }^{11} \mathrm{~B} /{ }^{10} \mathrm{~B}$ isotopic fractionation and the boron local environment in the structure of volcanic glasses. Geochim. Cosmochim. Acta 67, 1863-1873.

Tonarini, S., Leeman, W.P., Civetta, L., D’Antonio, M., Ferrara, G., Necco, A., 2004. B/Nb and $\delta^{11} \mathrm{~B}$ systematics in the Phlegrean Volcanic District, Italy. J. Volcanol. Geotherm. Res. 133, $123-139$.

Trave, A., Tangney, P., Scandolo, S., Pasquarello, A., Car, R., 2002. Pressure-induced structural changes in liquid $\mathrm{SiO}_{2}$ from ab initio simulations. Phys. Rev. Lett. 89, 245504.

Trumbull, R.B., Slack, J.F., 2018. Boron Isotopes in the Continental Crust: Granites, Pegmatites, Felsic Volcanic Rocks, and Related Ore Deposits. In: Marschall, H., Foster, G. (Eds.), Boron Isotopes: The Fifth Element. Springer International Publishing, Cham, pp. 249-272.

Trumbull, R.B., Beurlen, H., Wiedenbeck, M., Soares, D.R., 2013. The diversity of B-isotope variations in tourmaline from rare-element pegmatites in the Borborema Province of Brazil. Chem. Geol. 352, 47-62.

Urey, H.C., 1947. The thermodynamic properties of isotopic substances. J. Chem. Soc. 562-581. Vashishta, P., Kalia, R.K., Rino, J.P., 1990. Interaction potential for $\mathrm{SiO}_{2}$ : A molecular dynamics study of structural correlations. Phys. Rev. B 41, 12197-12209.

Vuilleumier, R., Sator, N., Guillot, B., 2009. Computer modeling of natural silicate melts: what can we learn from ab initio simulations. Geochim. Cosmochim. Acta 73, 6313-6339. 
Wang, W., Zhou, C., Liu, Y., Wu, Z., Huang, F., 2019. Equilibrium Mg isotope fractionation among aqueous $\mathrm{Mg}^{2+}$, carbonates, brucite and lizardite: Insights from first-principles molecular dynamics simulations. Geochim. Cosmochim. Acta 250, 117-129.

Williams, L.B., Wieser, M.E., Fennell, J., Hutcheon, I., Hervig, R.L., 2001. Application of boron isotopes to the understanding of fluid-rock interactions in a hydrothermally stimulated oil reservoir in the Alberta Basin, Canada. Geofluids 1, 229-240.

Winkler, A., Horbach, J., Kob, W., Binder, K., 2004. Structure and diffusion in amorphous aluminum silicate: a molecular dynamics study. J. Chem. Phys. 120, 384-393.

Wu, J., Stebbins, J.F., 2010. Quench rate and temperature effects on boron coordination in aluminoborosilicate melts. J. Non-Cryst. Solids 356, 2097-2108.

Wu, J., Stebbins, J.F., 2013. Temperature and modifier cation field strength effects on aluminoborosilicate glass network structure. J. Non-Cryst. Solids 362, 73-81.

Wunder, B., Meixner, A., Romer, R.L., Wirth, R., Heinrich, W., 2005. The geochemical cycle of boron: Constraints from boron isotope partitioning experiments between mica and fluid. Lithos 84, 206-216.

Zheng, Y.F., 1993a. Calculation of oxygen isotope fractionation in hydroxyl-bearing silicates. Earth Planet. Sci. Lett. 120, 247-263.

Zheng, Y.F., 1993b. Calculation of oxygen isotope fractionation in anhydrous silicate minerals. Geochim. Cosmochim. Acta 57, 1079-1091.

Zheng, Y.F., 1995. Oxygen isotope fractionation in magnetites: structural effect and oxygen inheritance. Chem. Geol. 121, 309-316.

Zheng, Y.F., 1996. Oxygen isotope fractionations involving apatites: Application to paleotemperature determination. Chem. Geol. 127 (1-3), 177-187.

Zheng, Y.F., 1998. Oxygen isotope fractionation between hydroxide minerals and water. Phys. Chem. Miner. 25, 213-221. 
Zheng, Y.F., 1999. Oxygen isotope fractionation in carbonate and sulfate minerals. Geochem. J. $33,109-126$.

Zheng, Y.F., Wei, C.S., Zhou, G.T., Xu, B.L., 1998. Oxygen isotope fractionation in mantle minerals. Sci. China Ser. D Earth Sci. 41, 95-103.

Zheng, Z., Deng, X.H., Chen, H.J., Yue, S.W., Dong, L.H., Qu, X., Chen, Y.J., 2016. Fluid sources and metallogenesis in the Baiganhu W-Sn deposit, East Kunlun, NW China: Insights from chemical and boron isotopic compositions of tourmaline. Ore Geol. Rev. 72, 1129-1142.

Zhu, D., Bao, H., Liu, Y., 2015. Non-traditional stable isotope behaviors in immiscible silicamelts in a mafic magma chamber. Sci. Rep. 5, 17561. 


\section{Tables}

Table 1. The lattice parameters and calculation sets for the white mica models

\begin{tabular}{|c|c|c|c|c|c|c|c|}
\hline & $\begin{array}{c}\text { Boromuscovite } \\
\text {-A-1M }\end{array}$ & $\begin{array}{c}\text { Boromuscovite } \\
\text {-A-2M1 }\end{array}$ & $\begin{array}{c}\text { Boromuscovite } \\
\text {-B-1M }\end{array}$ & $\begin{array}{c}\text { Boromuscovite } \\
\text {-B-2M1 }\end{array}$ & $\begin{array}{l}\text { Boromuscovite } \\
\text {-C-2M1 }\end{array}$ & $\begin{array}{l}\text { Phengite-A- } \\
\text { 2M1 }\end{array}$ & $\begin{array}{c}\text { Phengite-B- } \\
\text { 2M1 }\end{array}$ \\
\hline Formula & $\begin{array}{c}\mathrm{KAl}_{2}\left(\mathrm{BSi}_{3} \mathrm{O}_{10}\right) \\
(\mathrm{OH})_{2}\end{array}$ & $\begin{array}{c}\mathrm{KAl}_{2}\left(\mathrm{BSi}_{3} \mathrm{O}_{10}\right) \\
(\mathrm{OH})_{2}\end{array}$ & $\begin{array}{c}\mathrm{KAl}_{2}\left(\mathrm{BSi}_{3} \mathrm{O}_{10}\right) \\
(\mathrm{OH})_{2}\end{array}$ & $\begin{array}{c}\mathrm{KAl}_{2}\left(\mathrm{BSi}_{3} \mathrm{O}_{10}\right) \\
(\mathrm{OH})_{2}\end{array}$ & $\begin{array}{c}\mathrm{KAl}_{2}\left(\mathrm{BSi}_{3} \mathrm{O}_{10}\right) \\
(\mathrm{OH})_{2}\end{array}$ & $\begin{array}{c}\mathrm{KAl}_{4}\left(\mathrm{BSi}_{7} \mathrm{O}_{20}\right) \\
(\mathrm{OH})_{4}\end{array}$ & $\begin{array}{c}\mathrm{K}_{2} \mathrm{Al}_{4}\left(\mathrm{BAlSi}_{6}\right. \\
\left.\mathrm{O}_{20}\right)(\mathrm{OH})_{4}\end{array}$ \\
\hline Supercell & $1 \times 1 \times 1$ & $1 \times 1 \times 2$ & $1 \times 2 \times 1$ & $1 \times 1 \times 1$ & $1 \times 1 \times 1$ & $1 \times 1 \times 1$ & $1 \times 1 \times 1$ \\
\hline$a(\AA)$ & 10.162 & 5.093 & 10.162 & 5.093 & 10.185 & 10.185 & 10.185 \\
\hline$b(\AA)$ & 5.081 & 8.818 & 10.162 & 5.093 & 5.093 & 5.093 & 5.093 \\
\hline$c(\AA)$ & 10.076 & 19.819 & 10.076 & 20.939 & 19.819 & 19.819 & 19.819 \\
\hline$\alpha\left(^{\circ}\right)$ & 95.611 & 94.864 & 95.611 & 99.66 & 92.805 & 92.805 & 92.805 \\
\hline$\beta\left(^{\circ}\right)$ & 95.611 & 87.195 & 95.611 & 99.66 & 92.805 & 92.805 & 92.805 \\
\hline$\gamma\left({ }^{\circ}\right)$ & 119.724 & 89.967 & 119.724 & 120.033 & 120.033 & 120.033 & 120.033 \\
\hline $\begin{array}{l}\text { Volume } \\
\left(\AA^{3}\right)\end{array}$ & 443.12 & 885.67 & 886.24 & 442.835 & 885.67 & 885.67 & 885.67 \\
\hline$N_{\text {atoms }}$ & 42 & 84 & 84 & 42 & 84 & 82 & 84 \\
\hline K-points & $2 \times 2 \times 2$ & $3 \times 2 \times 1$ & $2 \times 2 \times 1$ & $3 \times 3 \times 1$ & $2 \times 3 \times 1$ & $2 \times 3 \times 1$ & $2 \times 3 \times 1$ \\
\hline $\begin{array}{c}\text { Cut-off } \\
\text { energy }(e V)\end{array}$ & 800 & 800 & 800 & 800 & 750 & 750 & 750 \\
\hline q-points & 22 & 12 & 8 & 42 & 20 & 20 & 20 \\
\hline Quality & Fine & Fine & Fine & Fine & Fine & Fine & Fine \\
\hline
\end{tabular}

Note: 'Quality' is a data quality control tab and used to limit parameter sets, such as K-points, Cut-off energy, and q-points. Generally, 'Medium' gives sufficient precision. 'Fine' means more accurate results with the expense of longer calculation time.

K-points: used for Brillouin zone sampling; the magnitude of the error in the total energy can be reduced by using a denser set of k-points.

Cut-off energy: the periodic system (mineral model) is calculated by plane wave basis sets; a higher cut-off energy corresponds to the use of more plane waves to describe the system.

q-points: used in the real space dynamical matrix calculations to obtain a set of frequencies at each point.

Table 2. Equations describing boron isotope-geothermometers in coexisting white micatourmaline

\begin{tabular}{lc}
\hline \multicolumn{1}{c}{ Description } & $y=1000 / \mathrm{T}(\mathrm{K}), x=\Delta^{11} \mathrm{~B}_{\text {mica-tur }}$ \\
\hline Average temperature & $y=0.360-0.098 x-0.0013 x^{2}$ \\
Upper-limit temperature & $y=0.360-0.114 x-0.0016 x^{2}$ \\
Lower-limit temperature & $y=0.360-0.086 x-0.0010 x^{2}$ \\
\hline
\end{tabular}




\section{Fig 1.}

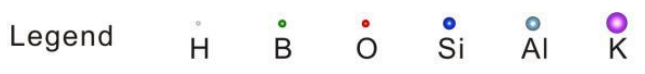

Boromuscovite-A-1M (B:Si=1:3)
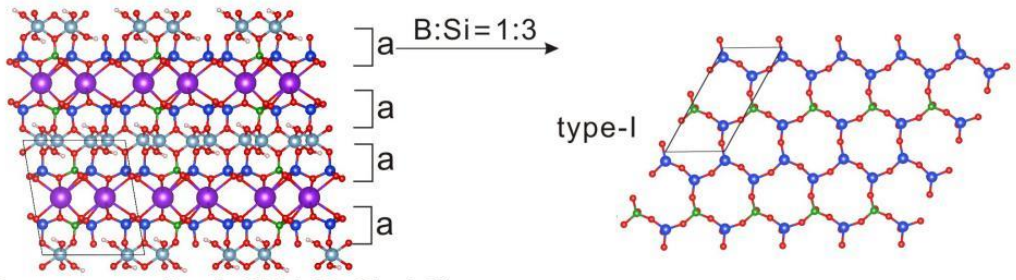

Boromuscovite-A-2M1 (B:Si=1:3)
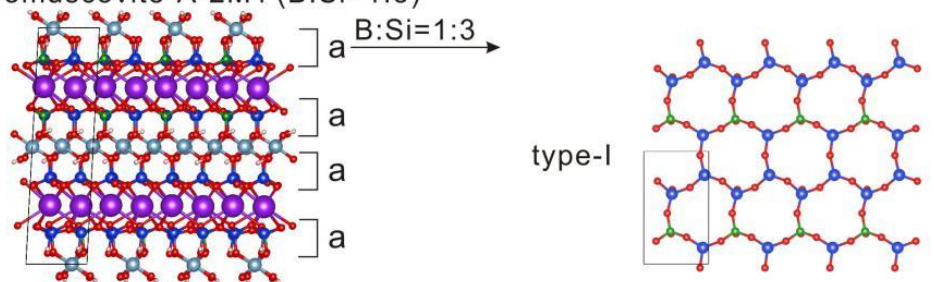

Boromuscovite-B-1M (B:Si=1:3)
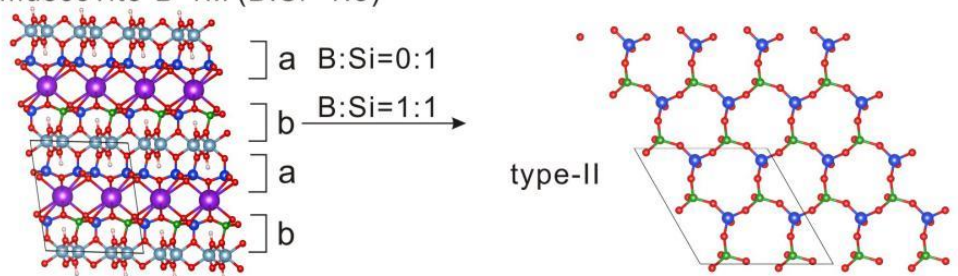

Boromuscovite-B-2M1 (B:Si=1:3)
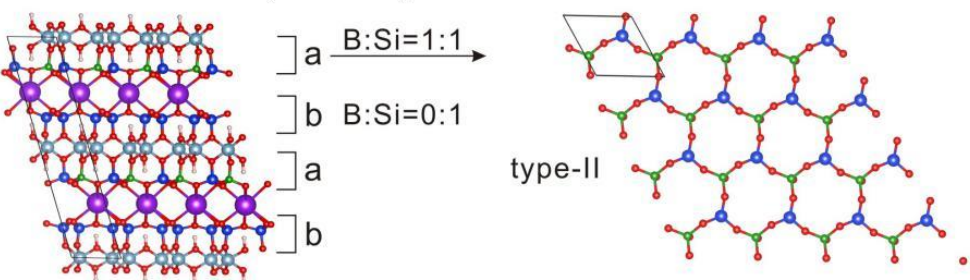

Boromuscovite-C-2M1 (B:Si=1:3)
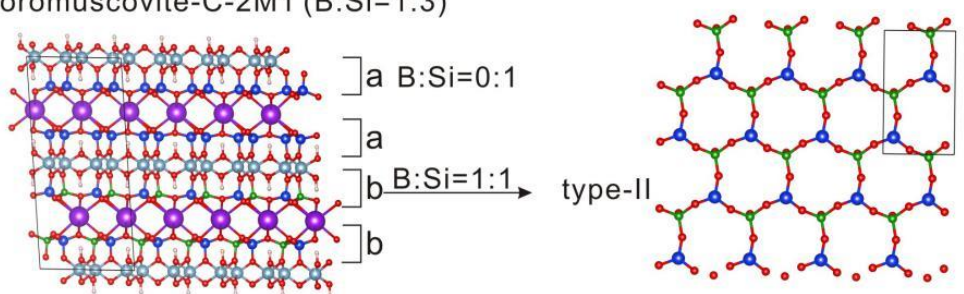

Phengite-A-2M1 (B:Si=1:7)

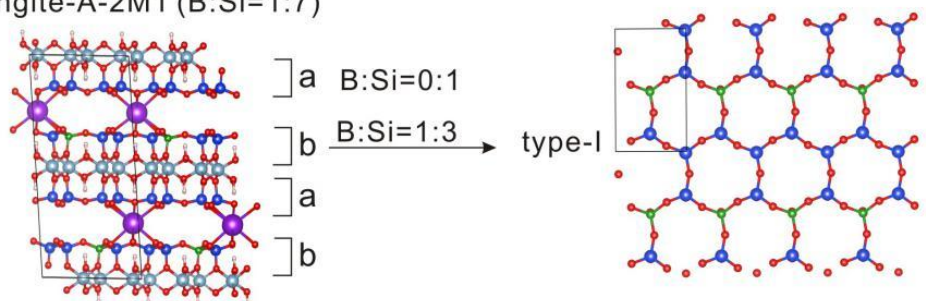

Phengite- $\mathrm{B}-2 \mathrm{M} 1(\mathrm{~B}: \mathrm{Si}=1: 6)$

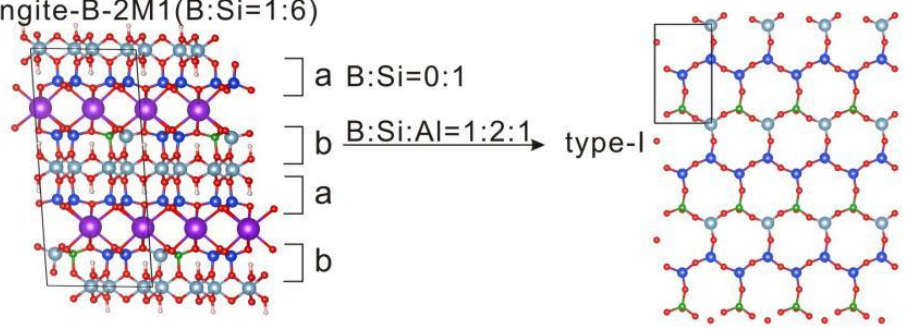


Fig 2.
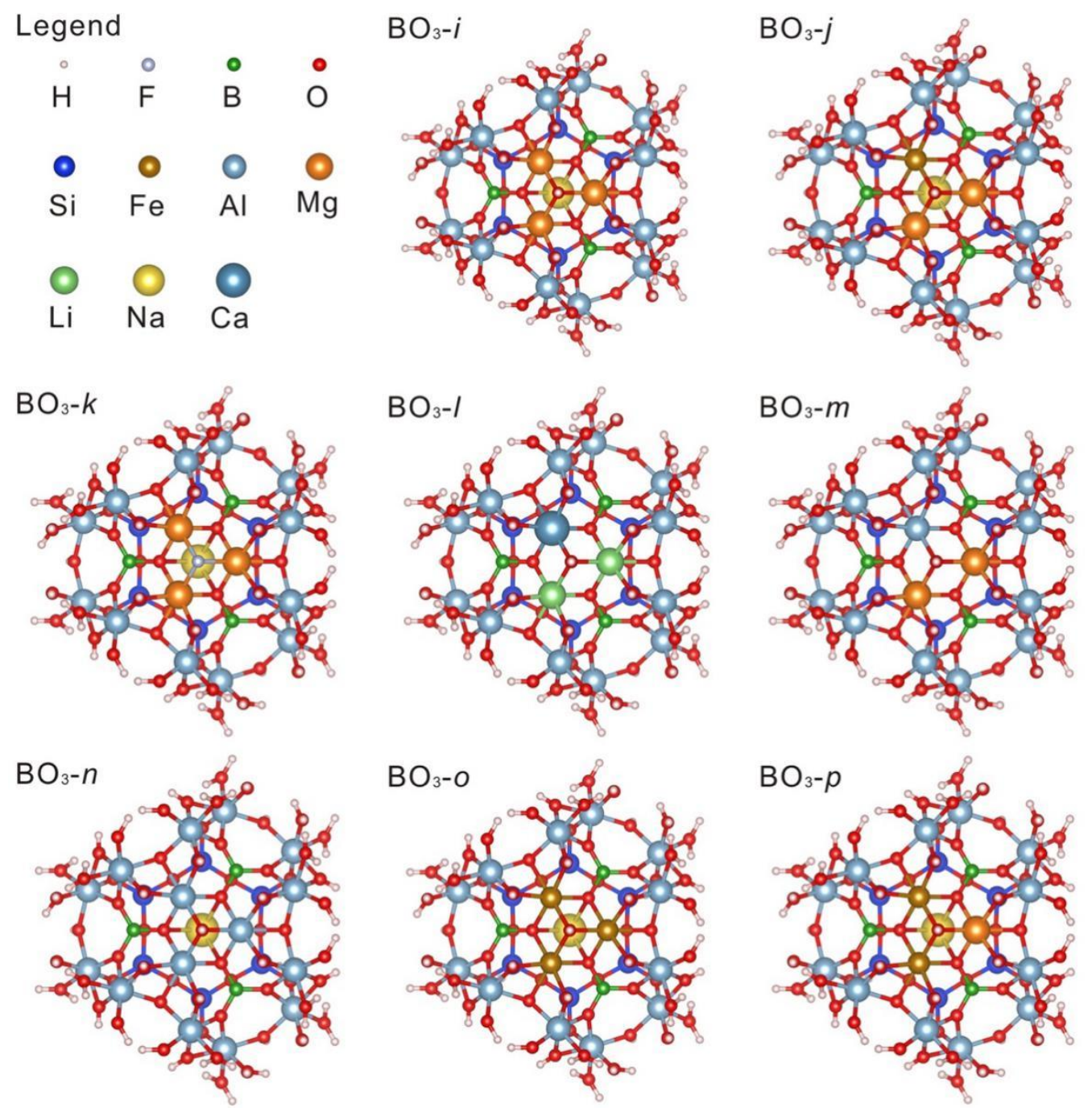

$\mathrm{BO}_{4}-i$

$\mathrm{BO}_{4}-j$

$\mathrm{BO}_{4}-k$
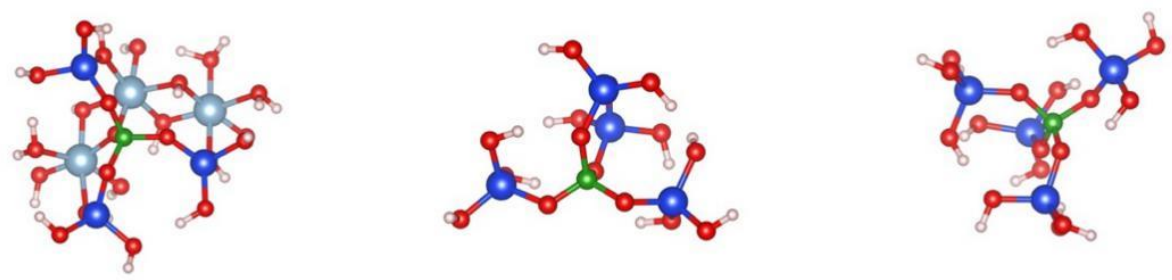

$\mathrm{BO}_{4}-\mathrm{I}$

$\mathrm{BO}_{4}-m$
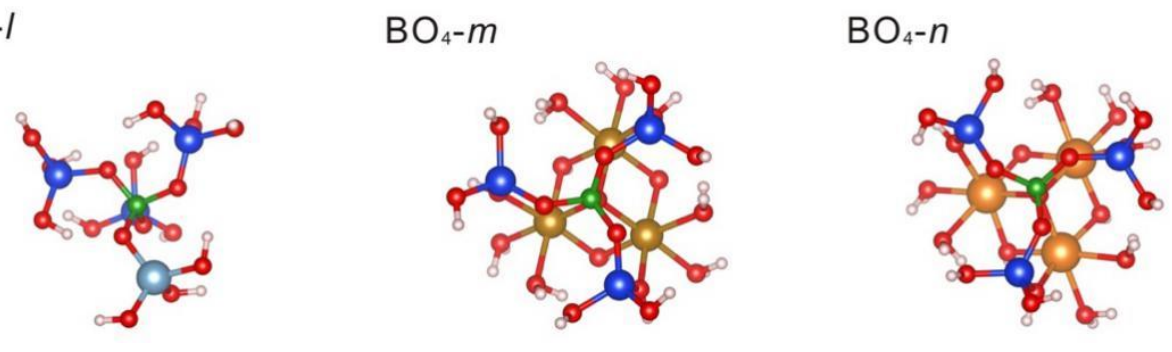
Fig. 3.
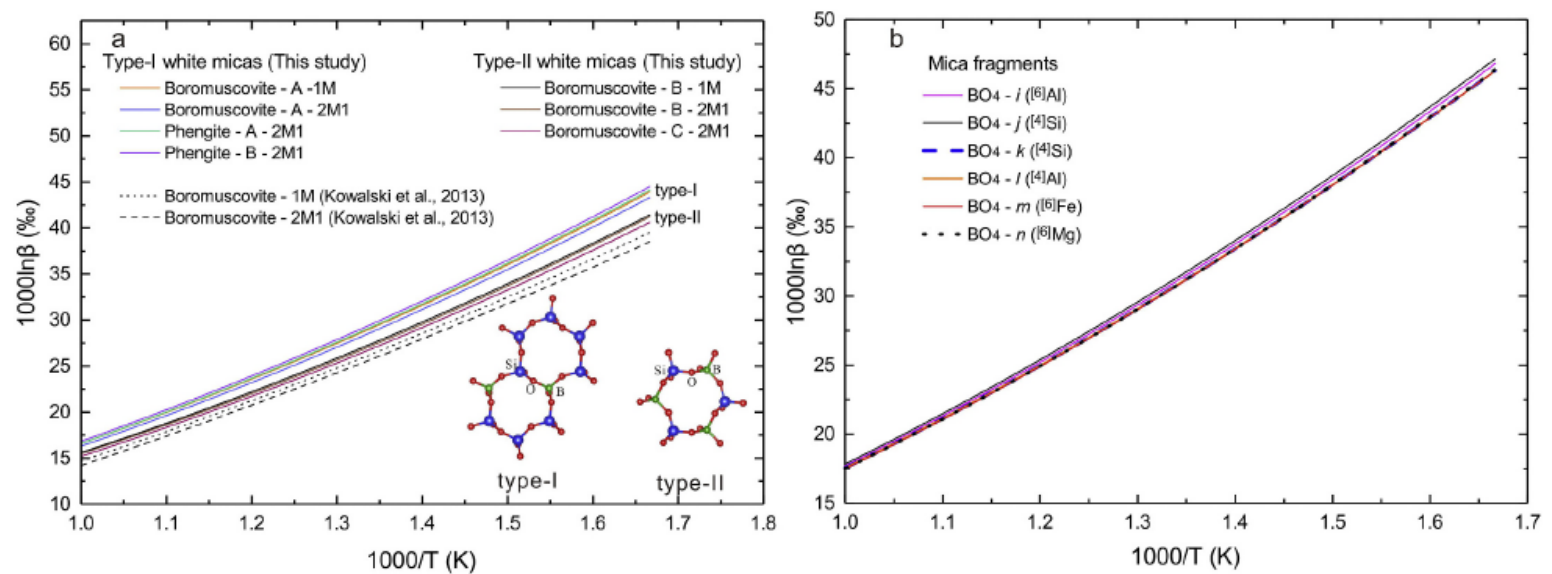

Fig. 4.
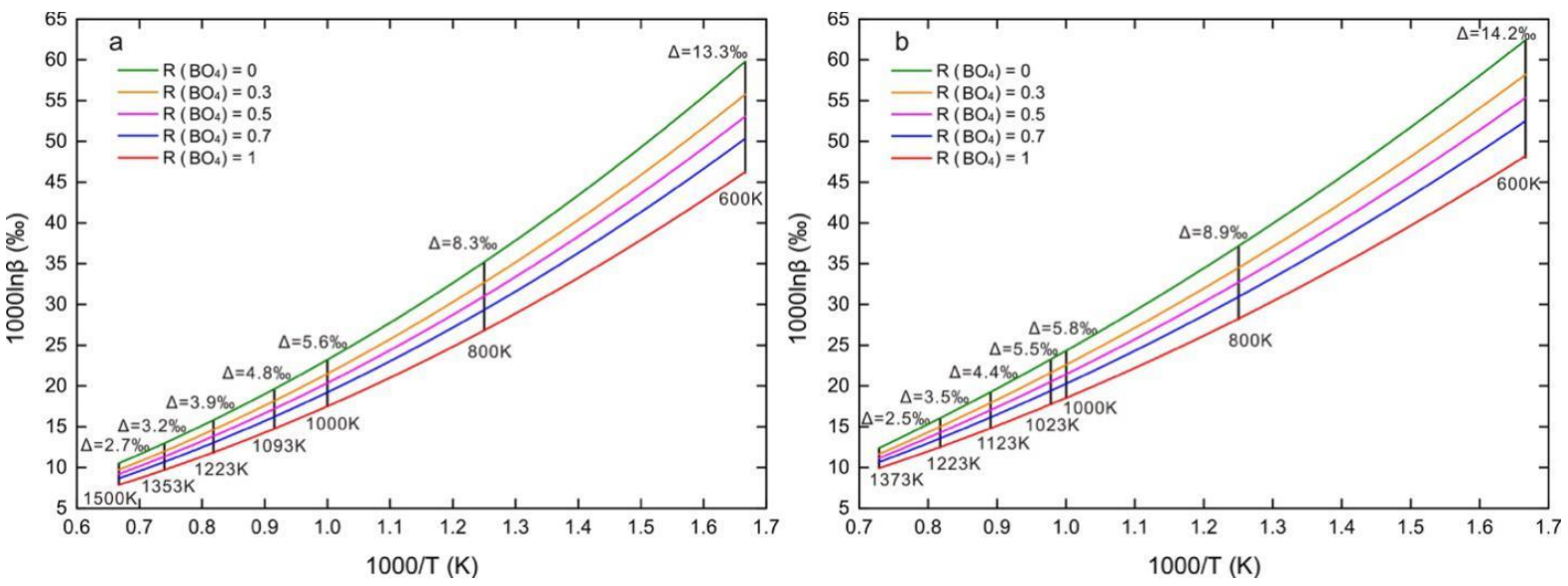

Fig. 5.
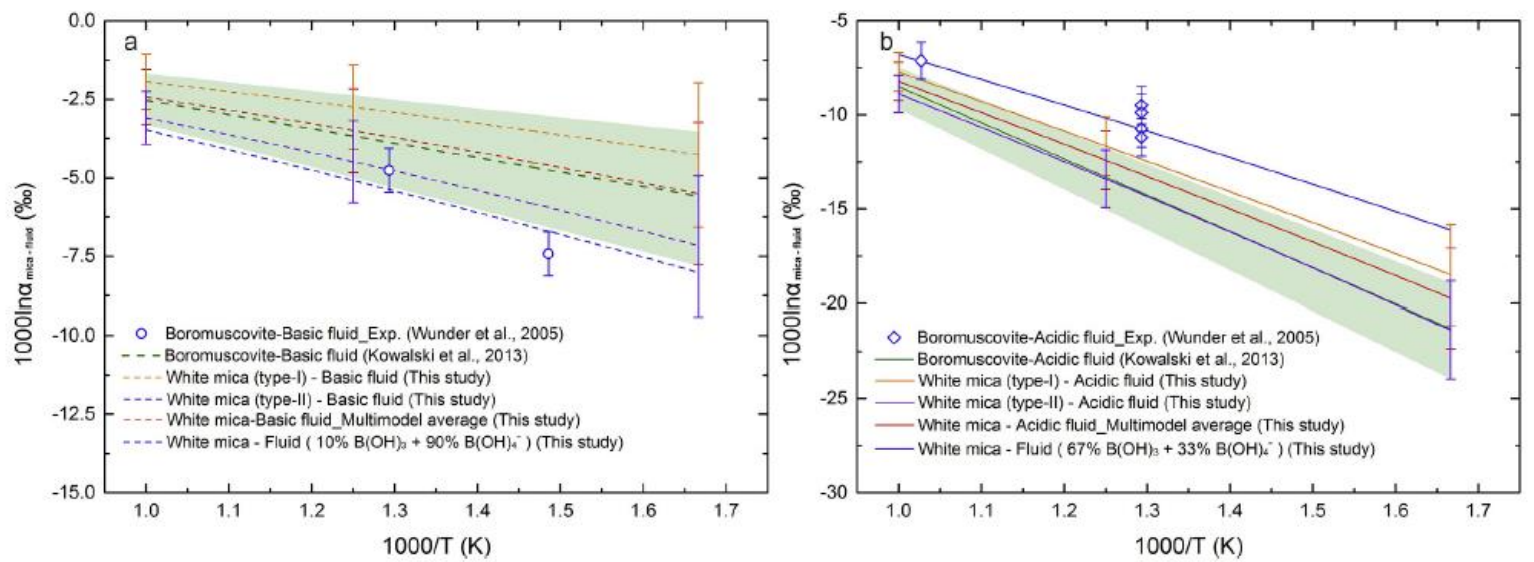
Fig. 6.

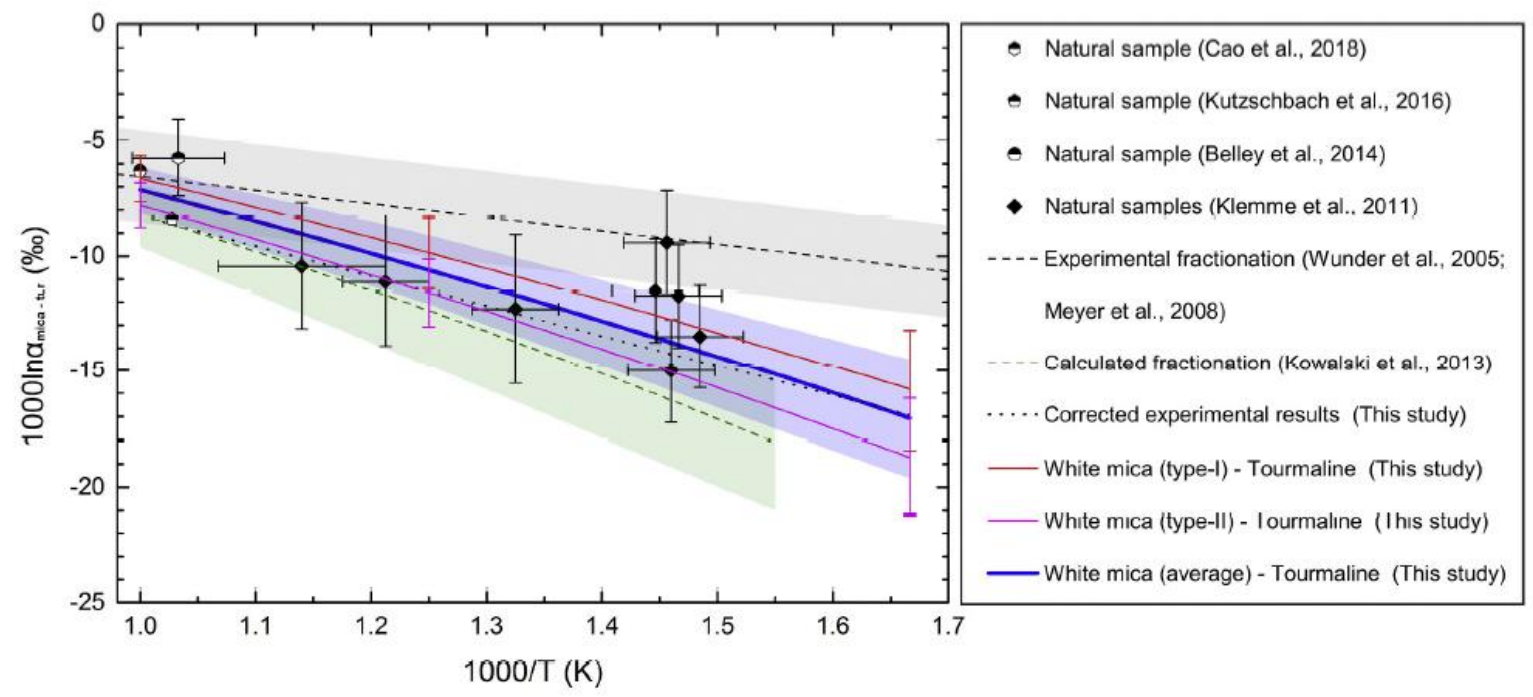

Fig. 7.
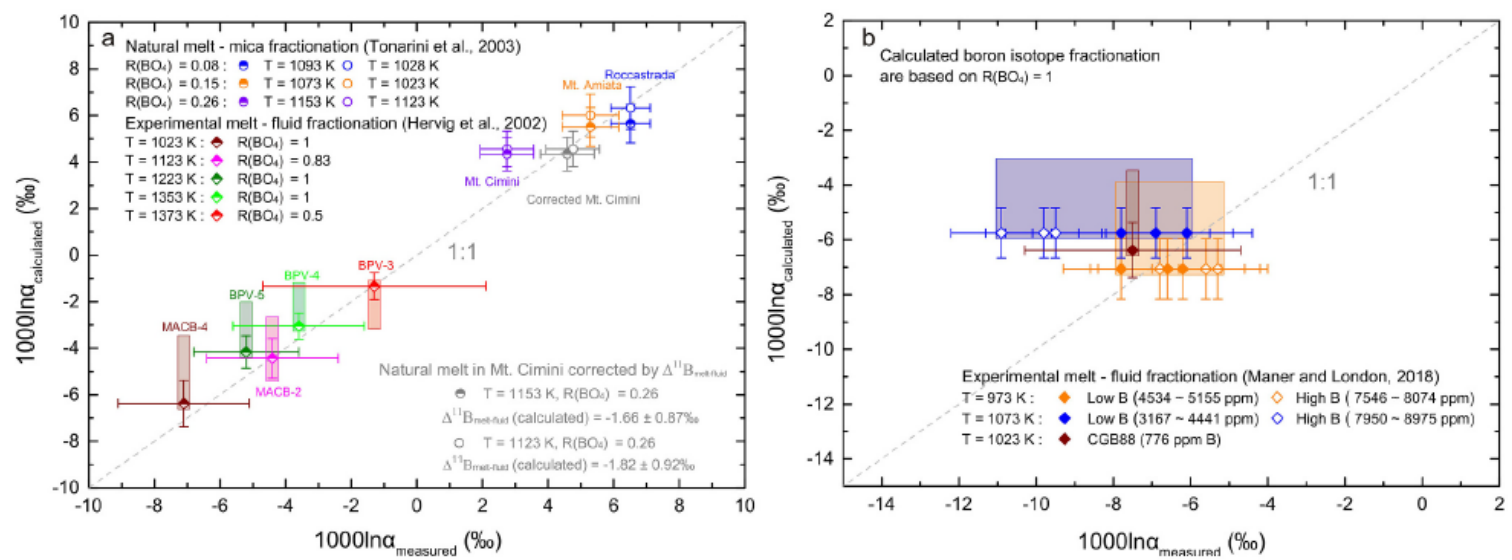

Fig. 8.

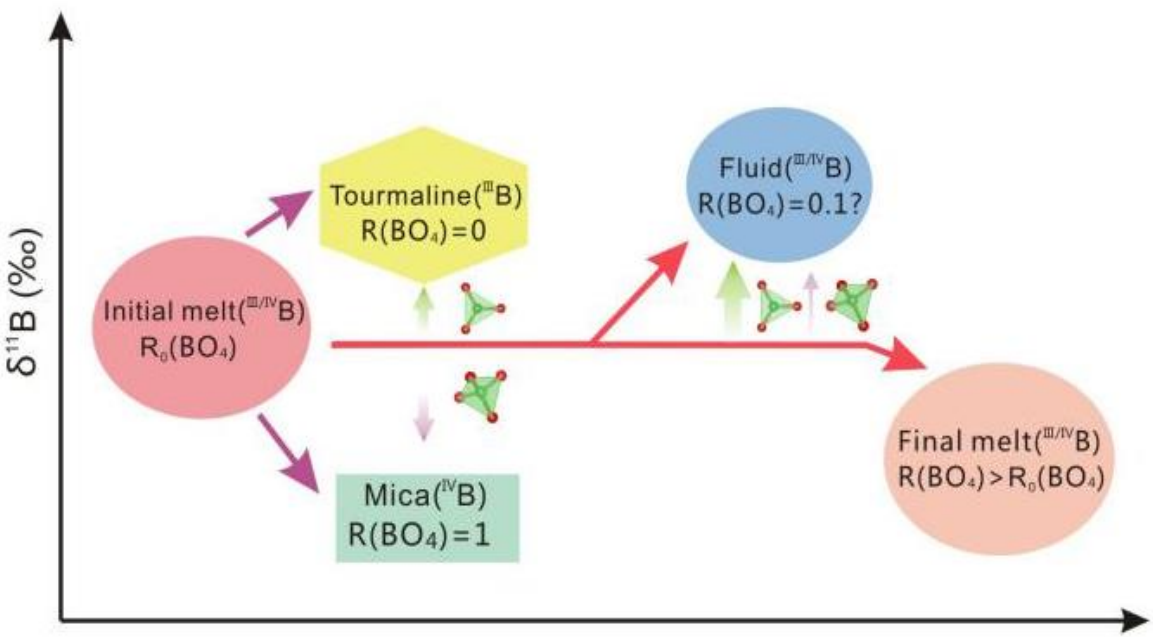

Time 
Fig. 9.

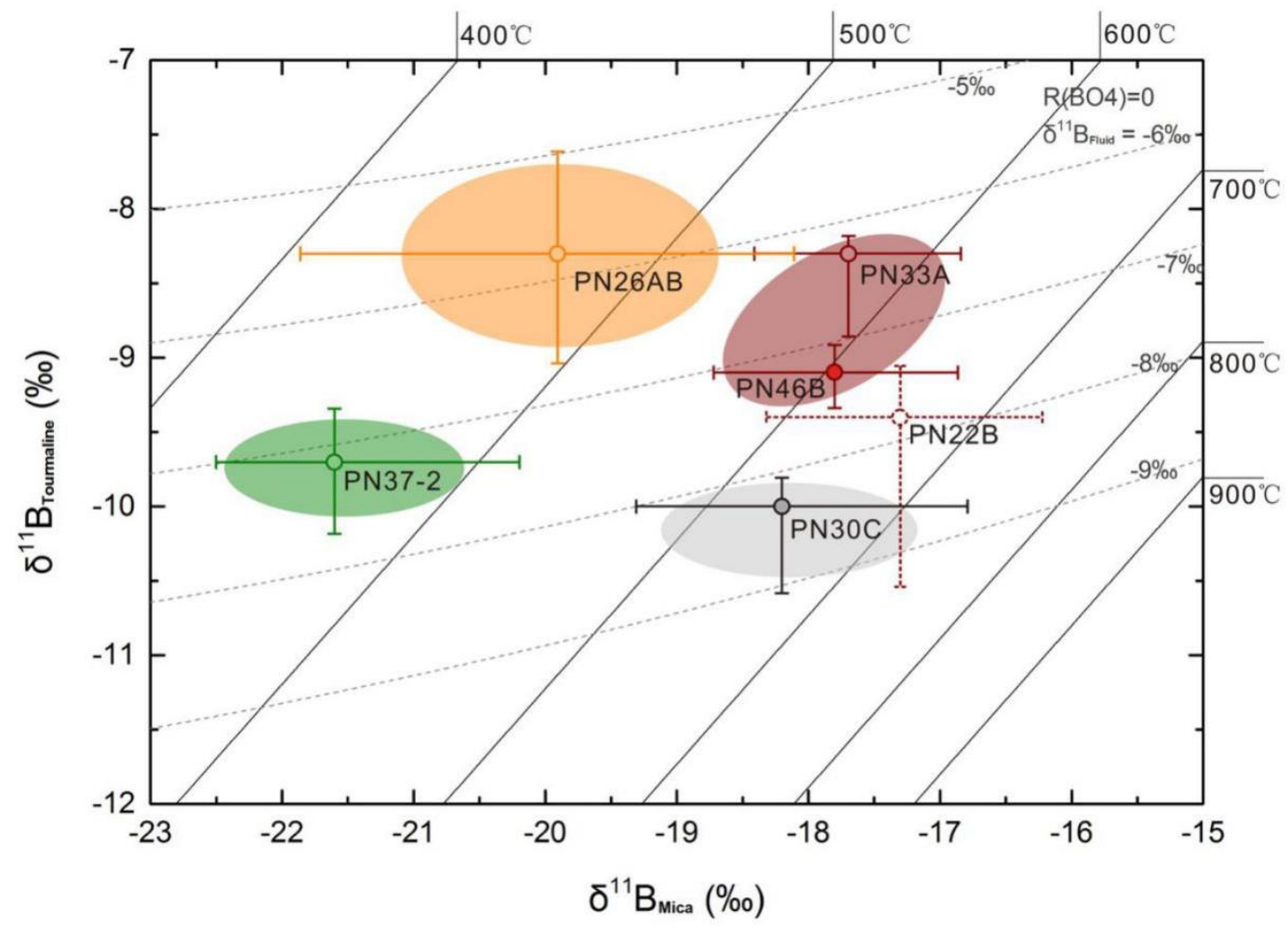

Fig. 10.

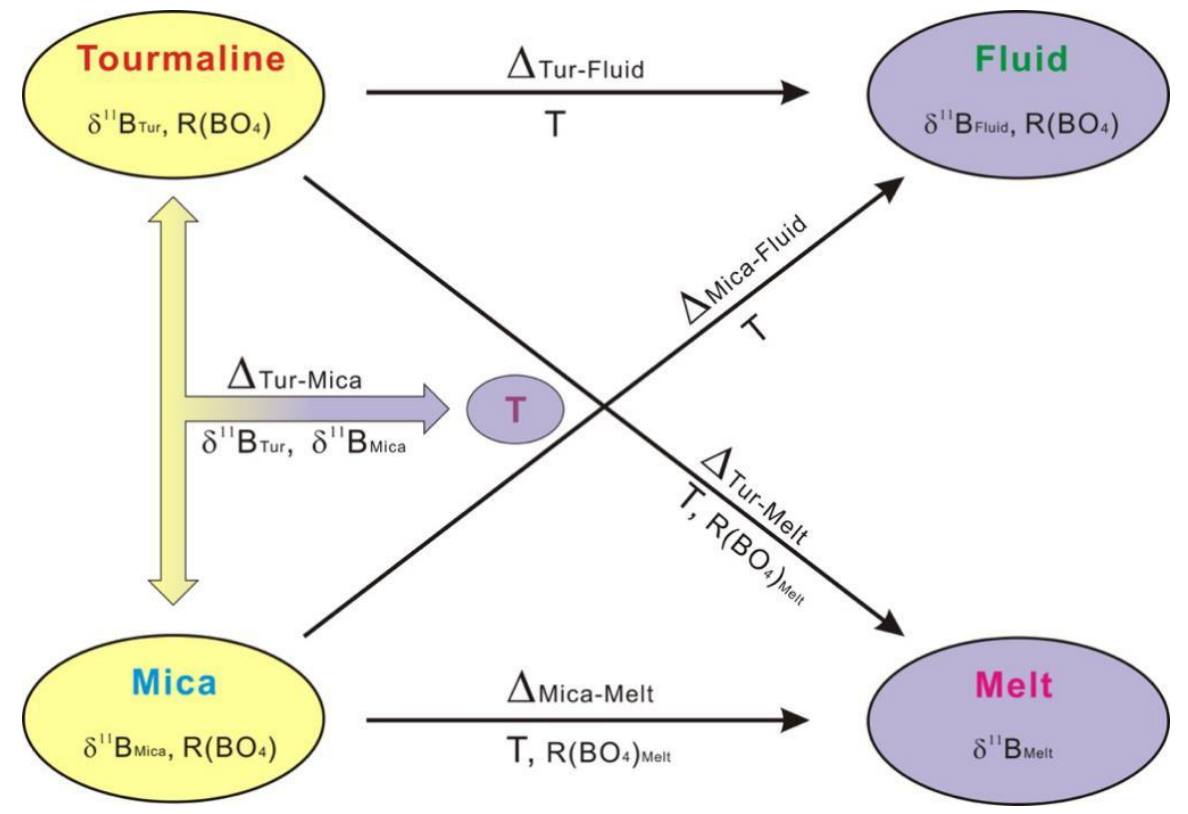


Fig. 11.

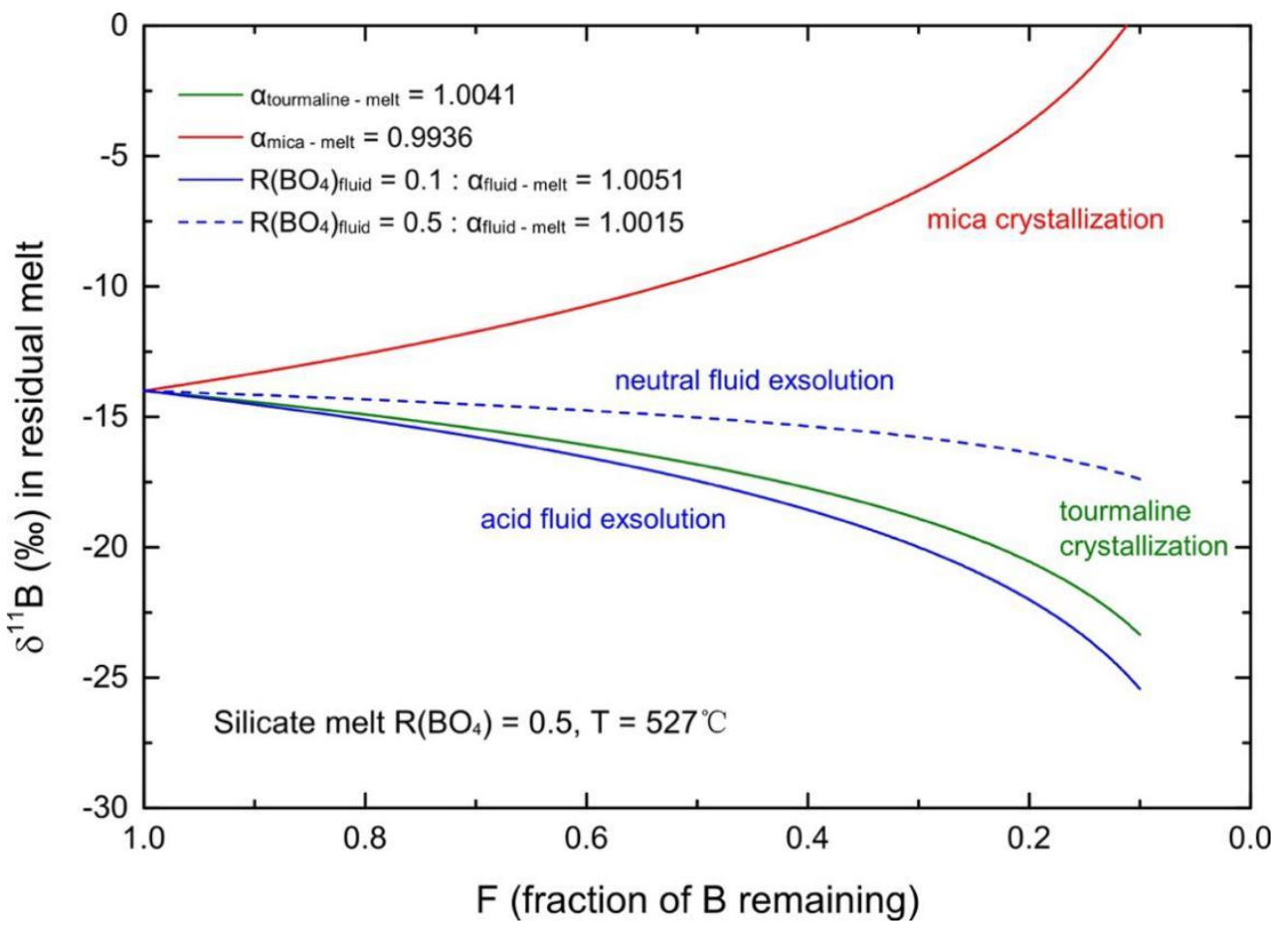




\section{Figure Captions}

Fig. 1. A series of periodic boundary cell (PBC) models for white mica (left) and the arrangement of boron atoms in silica tetrahedral layers (right). The letters A, B and C represent possible distributions of boron and silicon in the inter-layers of white mica structures along the $c$-axis.

Fig. 2. Cluster models representing $\mathrm{BO}_{3}$ and $\mathrm{BO}_{4}$ units in silicate melts with variable chemical compositions.

Fig. 3. Calculated $\beta$ values for (a) white micas with variable $\mathrm{B} / \mathrm{Si}$ ordering and (b) mica fragments with different chemical compositions.

Fig. 4. Calculated $\beta$ factors with variable proportions of the $\mathrm{BO}_{4}$ unit in silicate melt (a) and aqueous fluid (b). The $\beta$ factors of $\mathrm{BO}_{3}$ units in silicate melt are taken from Li et al. (2020) while those for the aqueous fluids are taken from Kowalski et al. (2013) and Li et al. (2020).

Fig. 5. Comparison of theoretically and experimentally determined boron isotope fractionation factors for white mica-basic fluid (a) and white mica-acid fluid (b). The species $\mathrm{B}(\mathrm{OH})_{3}$ and $\mathrm{B}(\mathrm{OH})_{4}{ }^{-}$are exclusively in the acidic and basic aqueous liquid, respectively. The experimental and calculated error bars correspond to $1 \sigma$; the data were fitted with linear regression. The $\beta$ factors for the aqueous liquid were derived from Li et al. (2020) and the study of Kowalski et al. (2013).

Fig. 6. Comparison of theoretically and experimentally determined boron isotope fractionation factors $\left(1000 \ln \alpha_{\text {mica-tur }}\right)$ between mica and tourmaline. The data for natural samples are cited from (Klemme et al., 2011; Belley et al., 2014; Kutzschbach et al., 2016; Cao et al., 2018). These data were fitted with a quadratic polynomial. The experimental fractionation was calculated from the experimental data of Meyer et al. (2008) and Wunder et al. (2005). The corrected experimental results were obtained by adjusting the original experimental fractionation factors using the difference between the experimental and theoretical fractionation factors for white mica-acid fluid in Fig. 5 b.

Fig. 7. (a) Comparison of measured and calculated 1000ln $\alpha$ factors for natural melt-mica systems and experimental melt-fluid systems; (b) Comparison of measured and calculated $1000 \ln \alpha$ factors for melt-fluid systems with different boron contents. The fraction of tetrahedrally coordinated boron in silicate melt is expressed as $\mathrm{R}\left(\mathrm{BO}_{4}\right)=\mathrm{BO} 4 /\left(\mathrm{BO}_{4}+\mathrm{BO}_{3}\right)$ and the vertical component of the shaded boxes shows the range of 1000ln $\alpha_{\text {calculated }}$ with $\mathrm{R}\left(\mathrm{BO}_{4}\right)$ values varying from 0.5 to 1 .

Fig. 8. A schematic diagram showing the paths of boron isotope variation with magma evolution. The superscripts III and IV refer to the boron coordination structures, $\mathrm{BO}_{3}$ and $\mathrm{BO}_{4}$ in the different phases.

Fig. 9. A plot of $\delta^{11} \mathrm{~B}$ for tourmaline versus $\delta^{11} \mathrm{~B}$ in mica showing isotherms (solid lines) for the equilibrium fractionation between the two minerals, based on the theoretical model presented in this study (Table 2, Figure 6). The dashed lines correspond to isopleths of $\delta^{11} \mathrm{~B}_{\text {fluid }}$ for different temperatures based on equilibrium boron isotope fractionation among white mica, tourmaline and fluid (Figure 5; Li et al., 2020; Kowalski et al., 2013). Areas shaded with grey, red, orange and green represent a quartz-chalcopyrite-wolframite vein (Sample PN30C), a 
quartz-mica-wolframite vein (Samples PN46B, PN33A), a cassiterite-quartz vein (Sample PN26AB) and a late fault zone (Sample PN37-2), all from the Panasqueira deposit, Portugal. The boron isotope SIMS data for the mica-tourmaline pairs were taken from Codeço et al. (2019).

Fig. 10. An illustration of how the boron isotope compositions of fluids and melts can be determined from the $\delta^{11} \mathrm{~B}$ values of the minerals of tourmaline and white mica that crystallized from them.

Fig. 11. Model curves illustrating the variations in $\delta^{11} \mathrm{~B}$ values in residual melt with a reduced fraction of boron (F) due to crystallization of tourmaline or mica, and after exsolution of aqueous fluid. The starting composition, $\delta^{11} \mathrm{~B}$ of $-14 \%$, corresponds to that in the Borborema leucogranite (Trumbull et al., 2013), whereas the boron isotope fractionation factors at $800 \mathrm{~K}$ were taken from this study. 